\title{
Foraminiferal record of the Middle Miocene climate transition prior to the Badenian salinity crisis in the Polish Carpathian Foredeep Basin (Central Paratethys)
}

\author{
Danuta PERYT ${ }^{1, *}$ \\ 1 Institute of Paleobiology, Polish Academy of Sciences, Twarda 51/55, 00-818 Warszawa, Poland
}

Peryt D. (2013) Foraminiferal record of the Middle Miocene climate transition prior to the Badenian salinity crisis in the Polish Carpathian Foredeep Basin (Central Paratethys). Geological Quarterly, 57 (1): 141-164, doi: 10.7306/gq.1080

Foraminifers occurring in marls underlying the Middle Miocene Badenian gypsum in the northern Polish Carpathian Foredeep in one borehole section [Młyny (Busko) PIG 1] and in two dewatering pits in operating quarries (Leszcze and Borków) contain well-preserved foraminifers. Sixty-seven species of benthic and twenty-one species of planktonic foraminifers are recorded in the 12-m-thick section of the Młyny borehole. Benthic assemblages are characterized by the dominance of Bulimina and Uvigerina while planktonic assemblages are composed mainly by warm-water orbulinids and Globigerinoides spp. in the lower part of the Młyny section and by temperate-cold water Globigerina spp. in the upper part of the Młyny section as well as the Leszcze and Borków sections. The taxonomic composition of foraminiferal assemblages makes it possible to distinguish two foraminiferal zones in the Młyny borehole: the Orbulina suturalis and Uvigerina costai zones, and only the latter zone is accessible at Leszcze and Borków. The benthic foraminiferal successions in the studied interval suggest oxygenation and productivity changes in the Carpathian Foredeep Basin prior to the Badenian salinity crisis. Four intervals of lowered oxygenation and/or elevated organic flux to the sea-floor are recognized; the intervals in which foraminiferal assemblages suggest marine environments with lowered oxygenation in bottom waters alternate between the intervals where stress markers form less than $50 \%$ of the benthic foraminiferal assemblages. Benthic assemblages are moderately to highly diversified, and species have more equal frequencies. The upsection decrease in the proportion of planktonic foraminifers reflects the shallowing of the basin accompanied by a decrease in the temperature gradient between the upper (warmer) and deeper (colder) water beds. The average palaeotemperature of water based on $\delta^{18} \mathrm{O}$ of Uvigerina and Globigerina decreased by ca. 2 and ca. $6^{\circ} \mathrm{C}$, respectively (from 9.9 and $17.4^{\circ} \mathrm{C}$ in the Orbulina suturalis Zone to 7.9 and $11.5^{\circ} \mathrm{C}$ in the Uvigerina costai Zone, respectively). Below the gypsum, the $\delta^{18} \mathrm{O}$ values of both benthic and planktonic foraminifers show quite large variations possibly due to the salinity increase. Coeval domination of benthic foraminiferal assemblages by Bulimina suggests increased surface water productivity and an increased organic flux to the sea-floor prior to the onset of evaporite deposition and/or salinity increase.

Key words: Middle Miocene, foraminifers, Paratethys, Badenian, salinity crisis, Carpathian Foredeep.

\section{INTRODUCTION}

The Paratethys was an epicontinental sea that developed as a relic of the Tethys. It existed from the Early Oligocene to late Middle Miocene times, and until the Middle Miocene it was in communication with the normal marine environments of the Mediterranean Basin and Indian Ocean (e.g., Harzhauser and Piller, 2007; Filipescu and Silye, 2008; Beldean et al., 2010). The repeated occurrence of isolation resulted in several salinity crises in the Carpathian region and other places in the Eastern Paratethys as well as in the Red Sea and the Middle East (Rögl, 1998; Popov et al., 2004). The Middle Miocene salinity crisis in the Central Paratethys started shortly after $13.81 \pm 0.08 \mathrm{Ma}$, as indicated by ${ }^{40} \mathrm{Ar} /{ }^{39} \mathrm{Ar}$ dating of volcanic tuffs below and within

*E-mail: d.peryt@twarda.pan.pl

Received: January 9, 2013; accepted: February 22, 2013; first published online: February 22, 2013 the Badenian salts in southern Poland (de Leeuw et al., 2010). The major step in Middle Miocene global cooling is dated at $13.82 \pm 0.03 \mathrm{Ma}$ in the Mediterranean (Abels et al., 2005) and because of this temporal relationship the cooling is interpreted to be the trigger of evaporite deposition (de Leeuw et al., 2010). The temperature decline after the Miocene climatic optimum (Böhme, 2003) that preceded evaporite deposition found its expression in the disappearance of warm-water planktonic foraminiferal assemblages and the expansion of the cool-water populations that was recorded both in the Paratethys (e.g., Szczechura, 1982; Gonera et al., 2000; Báldi, 2006; Kováčová et al., 2009) and the Tethys area (Bicchi et al., 2003). The signal of the Badenian cooling trend in the Carpathian Foredeep is stronger than in the Mediterranean (Bicchi et al., 2003) possibly due to the changing circulation (Báldi, 2006).

A pilot study of the uppermost part of marls (2-m-thick) underlying the Badenian gypsum in one locality in southern Poland (Borków, Nida River Valley; Fig. 1) showed that a clear environmental change took place during the deposition of the marls, from a middle to outer marine shelf, well-ventilated environment with moderate primary productivity to an inner shelf environment (Peryt and Gedl, 2010). The marls were deposited in 

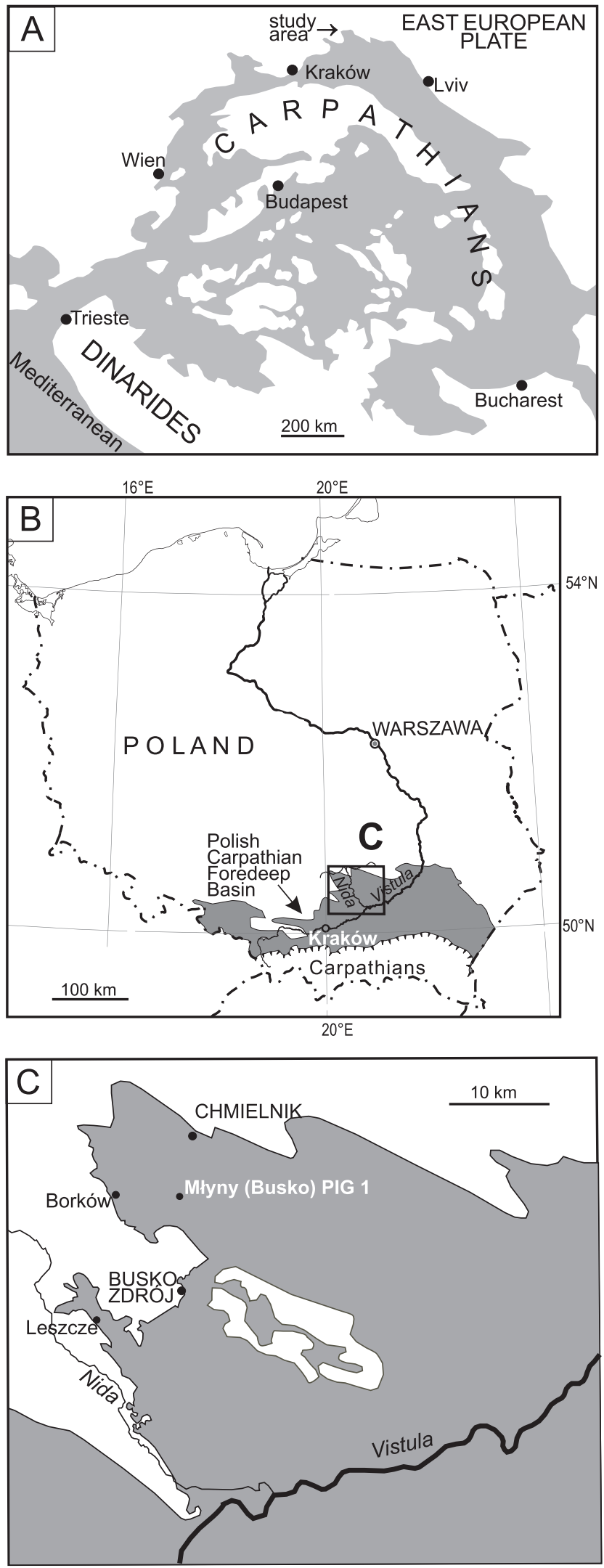

Fig. 1. Location map

A - palaeogeographic reconstruction of the Central Paratethys (Early Badenian marine sedimentation; after Rögl, 1998); B Carpathian Foredeep Basin in Poland (grey); C - location of sections studied (grey - occurrence of Badenian sulphates; after Kasprzyk, 1993, modified by Gonera et al., 2012, fig. 1) temperature-stratified water, and the calculated palaeotemperatures for particular foraminifer taxa (Globigerina spp., Cibicidoides spp. and Bulimina elongata) show a slight upsection decrease and a decrease in the temperature differences between the bottom and intermediate waters (Peryt and Gedl, 2010). At the Borków site there is a clear upsection decrease in the frequency of planktonic foraminifers within a $2 \mathrm{~m}$-interval of marls albeit the planktonic forms, although very rare, occur even below the gypsum, being accompanied by benthic taxa. Peryt and Gedl (2010) concluded that the time duration between the onset of the Badenian salinity crisis and the onset of gypsum precipitation was therefore much shorter than in the Messinian of the Mediterranean (about 60,000 years; Lozar et al., 2010).

The aim of this paper is to estimate temperature, depth, salinity, and oxygenation of the water column prior to Badenian evaporite sedimentation in the northern part of the Central Paratethys. To achieve this, foraminifers from marls which underlie the gypsum in one borehole section (Busko [Młyny] PIG 1) have been studied (Figs. 1 and 2). In addition, one key locality (Leszcze) and another locality (Borków), which was subject to a pilot study (Peryt and Gedl, 2010), were analysed (Figs. 1 and 3). The estimate of environmental factors such as depth, salinity, and oxygen content of water prior to evaporite sedimentation was done using the data on environmental requirements of recent Mediterranean foraminifers (see review in Murray, 1991, 2006). For more detailed environmental analysis of the marls, stable carbon and oxygen isotopes of selected foraminifer taxa have been studied.

\section{GEOLOGICAL SETTING}

The Badenian deposits in the northern part of the Carpathian Foredeep Basin in Poland lie transgressively on eroded Cretaceous and Jurassic strata (Radwański, 1969; Oszczypko et al., 2006). The Badenian section is tripartite owing to the occurrence of the Krzyżanowice Formation (gypsum deposits up to $50 \mathrm{~m}$ thick) in the middle. Below the gypsum various carbonate and siliciclastic rock units up to several tens of metres thick occur; they are included into the Pińczów Formation (Czapowski, 2004). The upper part of the Pińczów Formation is composed of marls of the Baranów Beds. These marls are several metres thick in the Borków area (Peryt and Gedl, 2010), they attain the thickness of ca. $10 \mathrm{~m}$ in the Gacki Quarry that is adjacent to the Leszcze Quarry (see Alexandrowicz and Parachoniak, 1956 and Babel et al., 2010, fig. 1C), and $100 \mathrm{~m}$ in the northern part of the Połaniec Trough (Wilczyński, 1984), a tectonic unit located east of the Borków gypsum quarry. In the marls tuffite intercalations occur: Bukowski (2011) recorded a thin $(6 \mathrm{~cm}$ thick) rhyolitic tuffite intercalation ca. $3.6 \mathrm{~m}$ below the gypsum base in the Młyny (Busko) PIG 1 borehole that can be correlated with the Wiatowice tuffite (Bukowski et al., 2010) and with the tuffite from Gacki (Dudek and Bukowski, 2004). In the marls rich foraminiferal assemblages are observed. Peryt and Gedl (2010) have shown the presence of 49 species of benthic foraminifers and 11 species of planktonics in a 2-m-thick marl outcropping in the Borków gypsum quarry, and Dudziak and Łuczkowska (1991) recorded 24 species (including two planktonic species, Globigerina decoraperta and Globigerina glutinata) in a sample occurring ca. $1 \mathrm{~m}$ below the top of the marls at Gacki and indicated that they represent the Uvigerina costai Zone.

The Badenian marls in the studied quarries are overlain by the giant gypsum intergrowths unit (see Babel, 1987) followed by bedded selenites with intercalations of alabastrine and 


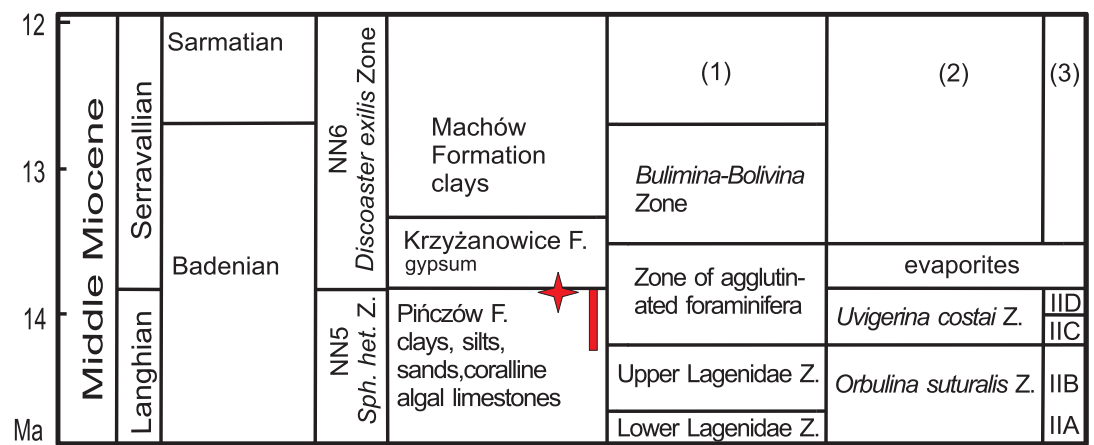

Fig. 2. Stratigraphic position of succession studied

Red asterisk for Leszcze and Borków sections and red bar for Młyny (Busko) PIG 1 borehole; the Miocene time scale after Hilgen et al. (2009), partly recalibrated and correlated to regional stages of the Central Paratethys; the lower limit of Badenian evaporites after de Leeuw et al. (2010); calcareous nannoplankton zones after Peryt (1997), NN5 Sph. het. Z = NN5 Sphenolites heteromorphous Zone; lithostratigraphy after Jasionowski (1997) and Oszczypko-Clowes et al. (2012); foraminiferal zones after: (1) - Mandic et al. (2002), (2) - Łuczkowska (1964) and Alexandrowicz (1963)
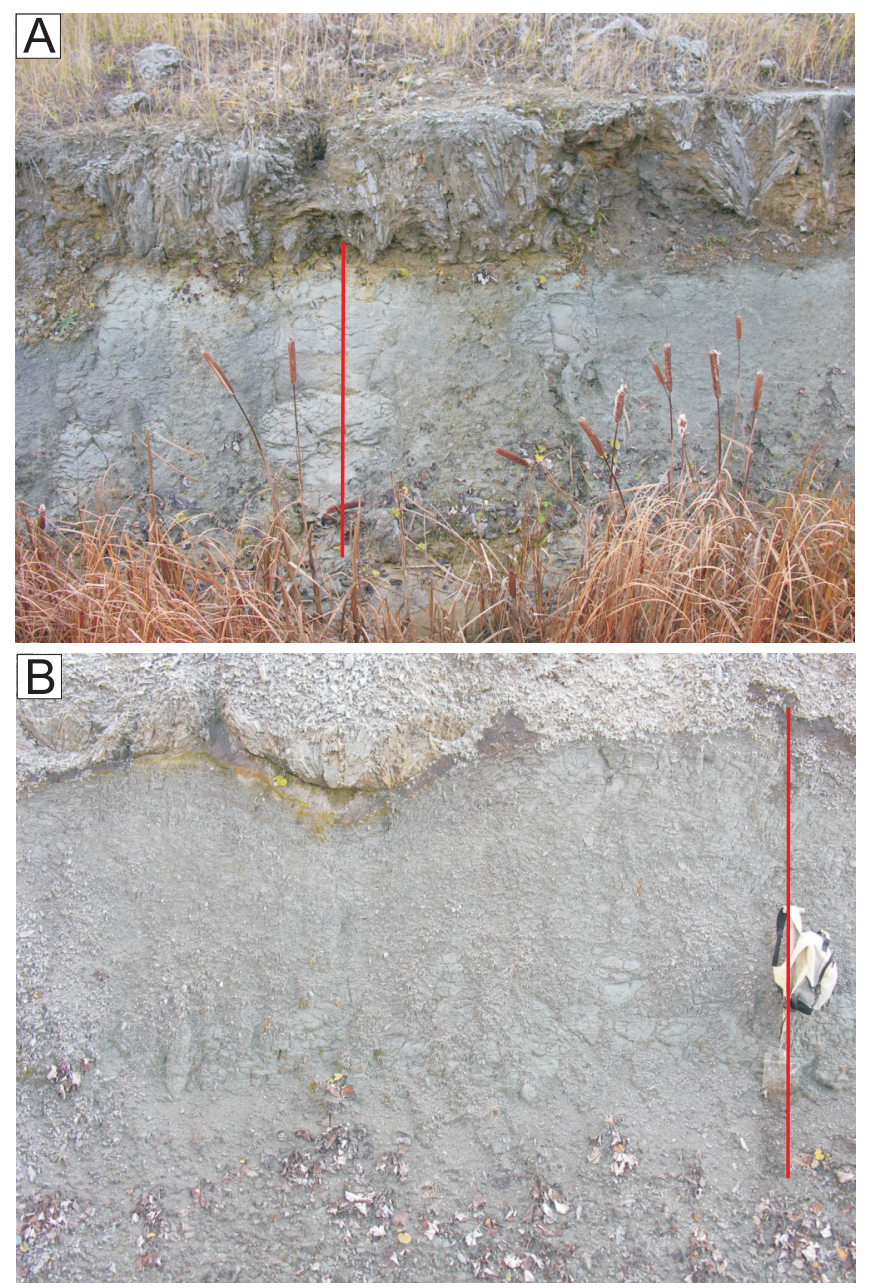

Fig. 3. Photographs of sampling sites

A - Leszcze, B - Borków; red lines (A - 1.25 m long; $B-2.4 \mathrm{~m}$ long) show the sections sampled stromatolitic gypsum, overlain by sabre gypsum. The upper part of the gypsum sequence consists primarily of various facies of clastic gypsum (Babel, 1991; Kasprzyk, 1991, 1993). In the Połaniec Trough the Badenian marls are overlain by nodular anhydrites considered by Kasprzyk (1991) to be sabkha deposits, however, such an interpretation contrasts with the general palaeogeographic pattern as the Młyny (Busko) PIG 1 borehole is located in the northern, more basinal location of the Połaniec Trough, and the Borków and Leszcze quarries are located in the Pińczów area, Nida River Valley, in a more nearshore location (Kwiatkowski, 1974). The gypsum section in the Młyny (Busko) PIG 1 borehole and Leszcze outcrop are covered by Upper Badenian siliciclastic facies (Machów Formation); at Borków, Quaternary siliciclastics occur above the gypsum, but in the sinkholes Upper Badenian marls with quite abundant foraminiferal assemblages can be found (Peryt, 2013).

\section{MATERIAL AND METHODS}

Seventy-four samples from three sections have been studied for foraminifers: 41 samples from the Młyny (Busko) PIG 1 borehole section (N 50³3'20.8', E 2044'04.9"; Fig. 1), 12 samples from the Leszcze Quarry N 50²7.315', E 20³6.180'; Fig. 3A) and 21 samples from the Borków Quarry (N 50³3.518', E 20³7.973'; Fig. 3B), in addition to five samples from the Borków Quarry studied previously (Peryt and Gedl, 2010).

In the Młyny (Busko) PIG 1 borehole, the interval underlying Badenian sulphates occurs at a depth of 188-200 m (the borehole was stopped then) and it consists of marls that are dark beige in colour in the lower part of the interval (195-200 m), then are beige (192-195 $\mathrm{m}$ ) and grey except in the uppermost part where they are black in colour. As already mentioned, a thin tuffite intercalation is seen at a depth of ca. $191.6 \mathrm{~m}$. In the lower part of studied interval, bivalves (either whole shells or their fragments) occur, and in the upper part phytogenic material occurs (G. Czapowski, pers. comm., 2010). In Leszcze and in Borków, sections 1.25 and $2.4 \mathrm{~m}$ thick, respectively, exposed in dewatering pits were studied; the section in Borków is located four metres apart from the section subject to pilot study (Peryt and Gedl, 2010, fig. 3C).

Washed residues for foraminiferal study were obtained from the rocks by disaggregation using $\mathrm{Na}_{2} \mathrm{SO}_{4}$. An aliquot of about 200-300 specimens of foraminifers from the $125-700 \mu \mathrm{m}$ size fraction was picked under a microscope for the faunal analyses. Well-preserved specimens were separated for isotopic analyses and then ultrasonically cleaned in order to remove particles adhered to the tests. The taxonomy of the foraminifers follows Loeblich and Tappan (1987), Odrzywolska-Bieńkowa and Olszewska (1996) and Cicha et al. (1998). The stratigraphically and palaeoenvironmentally important specimens were studied in detail and documented using a Philips XL20 SEM (Figs. 4-9).

The relative abundance of infaunal and epifaunal forms within benthic foraminiferal assemblages, simple benthic diversity, the Shannon-Weaver heterogeneity index $\mathrm{H}(\mathrm{S})$ (Buzas 
and Gibson, 1969), and planktonic foraminifers within total foraminiferal assemblages (P/B ratio) were calculated. The palaeoenvironmental interpretation based on foraminifers applies the requirements of present-day representatives of recorded taxa (Thomas, 1980; van der Zwaan, 1982; Culver, 1988; Lutze and Thiel, 1989; Verhallen, 1991; Murray, 1991, 2006; Sjoerdsma and van der Zwaan, 1992; Kaiho, 1994; Hohenegger, 2005; Kouwenhoven and van der Zwaan, 2006; Kaminski, 2012). Palaeobathymetry was estimated on the basis of benthic fauna characteristics and the P/B ratio $(100 \times$ planktonic foraminifera/total foraminifera).

Changes in water salinity and other environmental parameters such as productivity, oxygen level in bottom waters, were interpreted using qualitative and quantitative analyses (Murray, 2006). To estimate the level of oxygenation of the sea-floor the benthic foraminifera were grouped into oxic, suboxic and dysoxic indicators according to Thomas (1980), van der Zwaan (1982, 1983), Verhallen (1991), Jorissen et al. (1992), Kaiho (1994), Loubère (1996, 1997), Bernhard and Sen Gupta (1999), Kouwenhoven and van der Zwaan (2006) and Kaminski (2012).

The following taxa are included into the oxic group: Cibicidoides spp., Heterolepa dutemplei, Lobatula lobatula, Siphonina reticulata, Anomalinoides spp., Cibicides sp., Hansenisca soldanii, Oridorsalis umbonatus. Oxic indices represent epifaunally living species. Taxa tolerant of suboxic environments are: Lenticulina spp., Nodosaria spp., Laevidentalina spp., Melonis pompilioides, Pullenia bulloides, P. miocenica, Sphaeroidina bulloides, Cassidulina laevigata, Globobulimina pyrula, and taxa tolerant of dysoxic environments - Bolivina spp., Bulimina spp., Uvigerina spp., Fursenkoina acuta, Praeglobobulimina pyrula, Globocassidulina spp.

Foraminifers tolerant of suboxic environments represent mostly shallow infaunally living species, while foraminifers tolerant of dysoxic environments represent mostly deep infauna and species with opportunistic behaviour. They are commonly used as stress markers (e.g., van der Zwaan et al., 1999; van Hinsbergen et al. 2005).

Changes in planktonic foraminiferal assemblages were used to reconstruct palaeoclimatic changes. Planktonic foraminifera were grouped into cool-temperate indices (Globigerina bulloides, G. praebulloides, G. tarchanensis, G. diplostoma, G. concinna, Globorotalia bykovae) and warm indices (Orbulina suturalis, O. bisphaerica, Globigerinoides spp., Paragloborotalia mayeri, P. siakensis; Szczechura, 1982, 1984, 2000; Spezzaferi et al., 2002; Bicchi et al., 2003).

The $\delta^{18} \mathrm{O}$ and $\delta^{13} \mathrm{C}$ ratios of two foraminifer taxa: Globigerina (in most cases, G. bulloides) and Uvigerina (mostly $U$. aculeata), were studied in 52 samples to estimate absolute water temperature. In a few cases when Uvigerina specimens were too rare to allow for isotopic studies, I used Bulimina for that purpose, the taxon applied in the pilot study at Borków (Peryt and Gedl, 2010), as both had similar environmental requirements. I assume that the isotope values for Globigerina and Uvigerina are indicative of the surface and deep-water isotope composition, respectively. Foraminifer tests were reacted with $100 \%$ phosphoric acid at $75^{\circ} \mathrm{C}$ using a KIEL IV online automatic carbonate preparation line connected to the Finnigan Mat delta plus mass-spectrometer at the Light Stable Isotopes Laboratory of the Institute of Geological Sciences and Institute of Paleobiology, Polish Academy of Sciences, Warszawa. All isotopic data were reported in per mil relative to VPDB related to NBS 19. The precision (reproducibility of replicate analyses) of both carbon and oxygen isotope analyses was usually better than $\pm 0.2 \%$. To calculate palaeotemperatures, the equation established by Epstein et al. (1953) was applied.

The figured specimens are deposited in the Institute of Paleobiology, Polish Academy of Sciences, Warszawa (ZPAL F. 59).

\section{RESULTS}

\section{FORAMINIFERA}

\section{MŁYNY (BUSKO) PIG 1 BOREHOLE}

The examined sediments contain well-preserved foraminifers. Sixty-seven species of benthic and twenty-one species of planktonic foraminifers were recorded in the studied in-

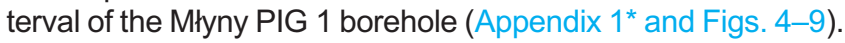
Benthic assemblages are characterized by the dominance of Bulimina and Uvigerina while planktonic ones are composed mainly of orbulinids and Globigerinoides spp. in the lower part of the section and of Globigerina spp. in its upper part.

Figure 10 shows the relative percent abundances of common and dominant species, i.e. species that show abundance $>5 \%$ in at least in one sample, the diversity of benthic assemblages, and relative abundances of planktonic and benthic foraminifers as well as relative abundances of dysoxic, suboxic and oxic species or groups of species.

In the Młyny (Busko) PIG 1 section, simple species diversity of benthic foraminifers is low to moderate and varies between 8 and 26 . $H(S)$ values vary between 1.8 and 2.8. Lowest values correspond to low diversified and with high dominance benthic foraminiferal assemblages, which in this section correlate with assemblages where deep infaunal species (= stress markers) are dominant

Benthic foraminiferal assemblages are dominated by calcareous forms; agglutinated foraminifera are represented by only four species: Vulvulina pennatula, Spiroplectinella carinata, Spirotextularia cf. fistulosa and Martinotiella communis. They are present mainly only in the lower part of the studied interval and completely disappear $6 \mathrm{~m}$ below the base of the gypsum except for Martinotiella communis which is also recorded in small numbers in the upper part of section. The agglutinants are a minor contributor to the assemblages and usually do not exceed $10 \%$ except of the $2-m$-thick interval in the lower part of the section where they form up to $20 \%$ of the assemblages.

Heterolepa dutemplei is a common component of the lower and middle parts of the section. Its contribution to assemblages varies from 2 to $20 \%$. Cibicidoides spp., Melonis pompilioides, Pullenia miocenica, Sphaeroidina bulloides are recorded in the entire section but their abundances fluctuate. In places they form up to $20 \%$ of the assemblages. Nodosariaceans are common in the lower part of the section, then, in its middle part, they are not recorded and they reappear in small numbers in the upper part of the section. In that part of the section the first occurrences of two species were found: Hoeglundina elegans which about $2 \mathrm{~m}$ below the gypsum forms $20 \%$ of the assemblage and Fursenkoina acuta which at the level about $1 \mathrm{~m}$ below the gypsum forms 25\% (Fig. 10).

Bulimina and Uvigerina are the dominant foraminifers in the whole section. The abundances of the two groups fluctuate sig- 

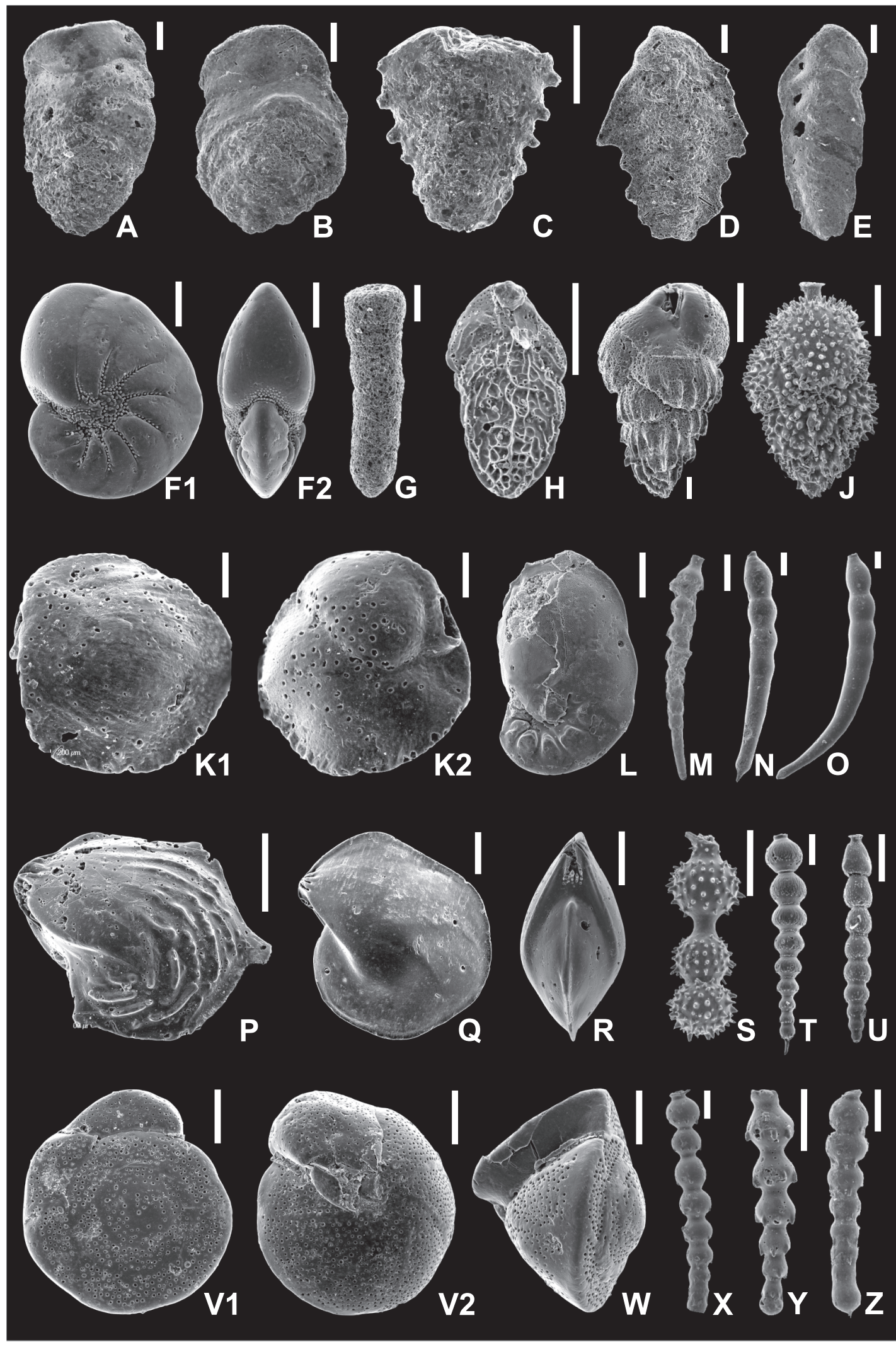

Fig. 4. Benthic foraminifers from the Młyny (Busko) PIG 1 borehole

A, B - Vulvulina pennatula; C - Spirotextularia cf. fistulosa; D - Spiroplectinella carinata; E - Spiroplectinella sp.; F1, F2 - Nonion commune; G - Martinotiella communis; H - Bolivina viennensis; I - Bulimina striata; J - Uvigerina pygmea; K1, K2 - Siphonina reticulata; L - Cancris auriculus; M-O - Laevidentalina elegans; $\mathbf{P}$ - Lenticulina echinata; Q, R - Lenticulina inornata; S - Nodosaria hispida; T, X, Z - Stilostomella adolphina; U - Stilostomella sp. 1; V1, V2, W - Heterolepa dutemplei; Y - Stilostomella lepidula; scale bar is $200 \mu \mathrm{m}$; A, C, G, N, S-U, W - sample 38; B, D, H-L, O, P, V-sample 41; E, R-sample 37; F, Q-sample 36; I, M, X, Y - sample 24; M, Z - sample 21 

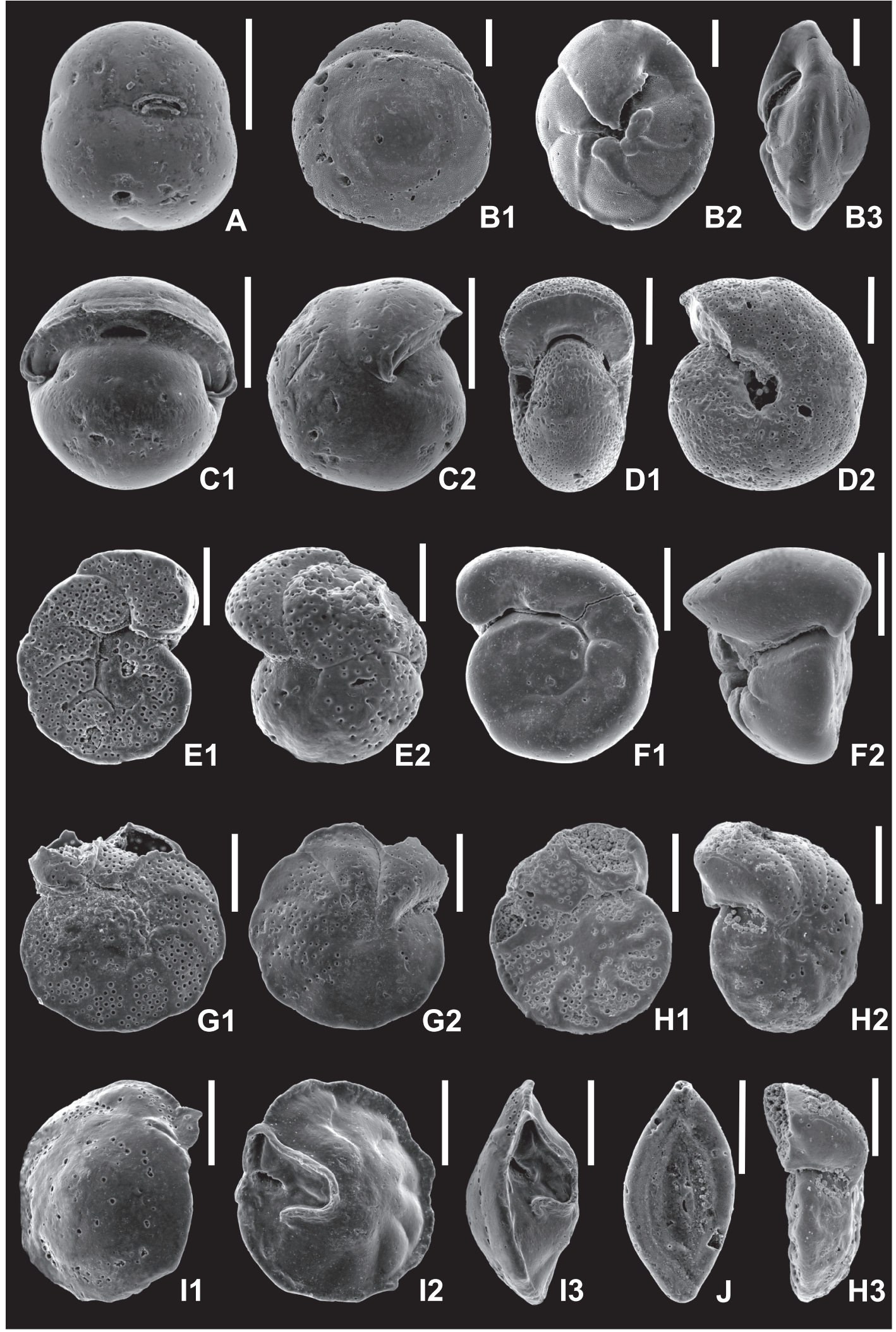

Fig. 5. Benthic foraminifers from the Młyny (Busko) PIG 1 borehole

A - Sphaeroidina bulloides; B1-B3 - Neoeponides schreibersi; C1, C2 - Pullenia miocenica; D1, D2 - Melonis pompilioides; E1, E2 - Lobatula lobatula; F1, F2 - Hansenisca soldanii; G1, G2 - Cibicidoides ungerianus; H1-H3 Cibicidoides austriacus; I1-I3 - Oridorsalis umbonatus; J - Sigmoilinita tenuis; scale bar is $200 \mu \mathrm{m}$; A, E - sample 38; B - sample 37; C, D - sample 20; F-I - sample 41; J - sample 9 

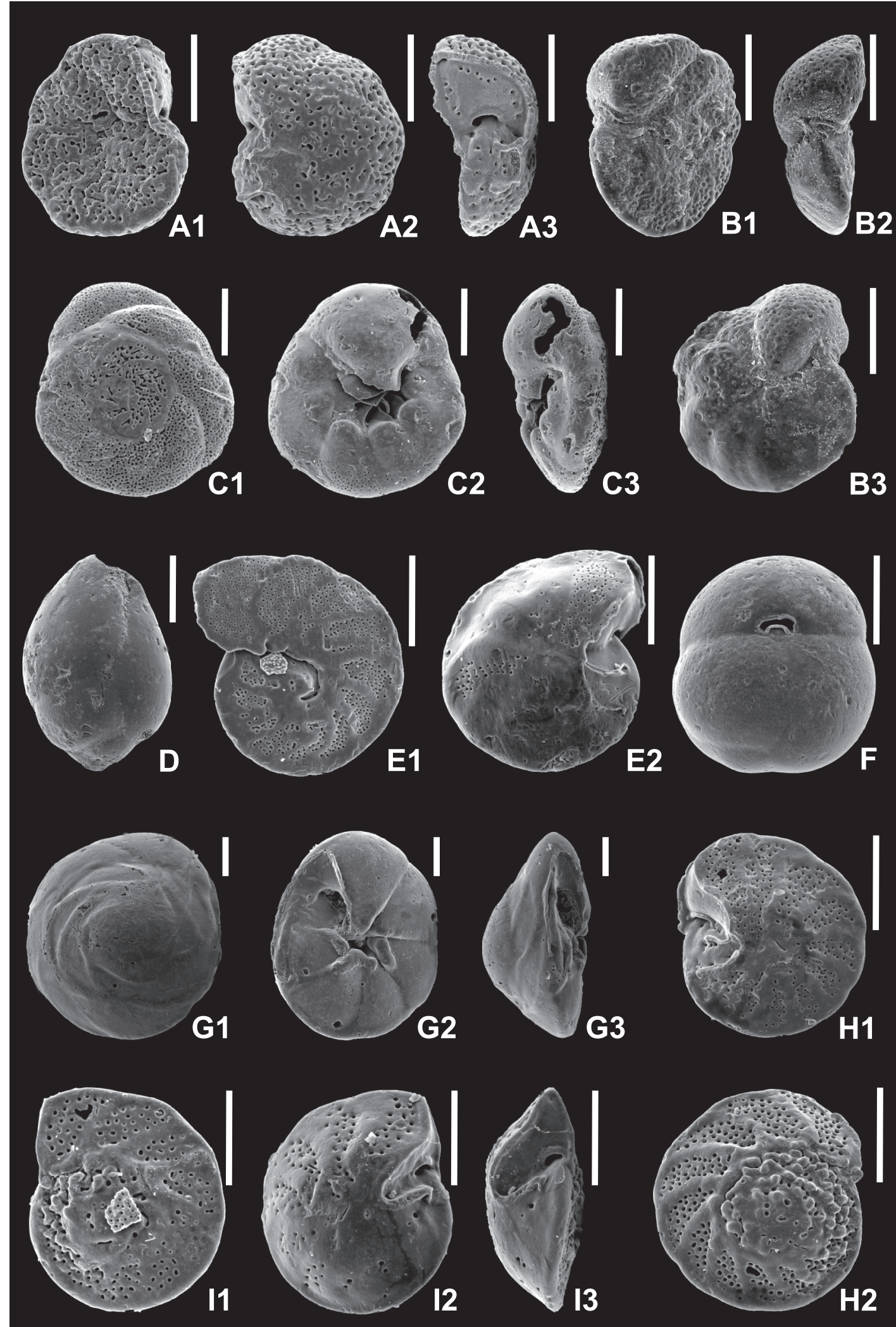

Fig. 6. Benthic foraminifers from the Młyny (Busko) PIG 1 borehole

A1-A3 - Anomalinoides badenensis; B1-B3 - Anomalinoides sp.; C1-C3 - Valvulineria complanata; D Globobulimina pyrula; E1, E2 - Cibicides sp.; F - Sphaeroidina bulloides; G1-G3 - Neoeponides schreibersi; H1 H2 - Cibicidoides ungerianus; I1-I3 - Cibicidoides pseudoungerianus; scale bar is $200 \mu \mathrm{m} ; \mathrm{A}, \mathrm{C}$ - sample 14; B sample 21; D - sample 12; E, H, I - sample 7; F - sample 9; G - sample 36 


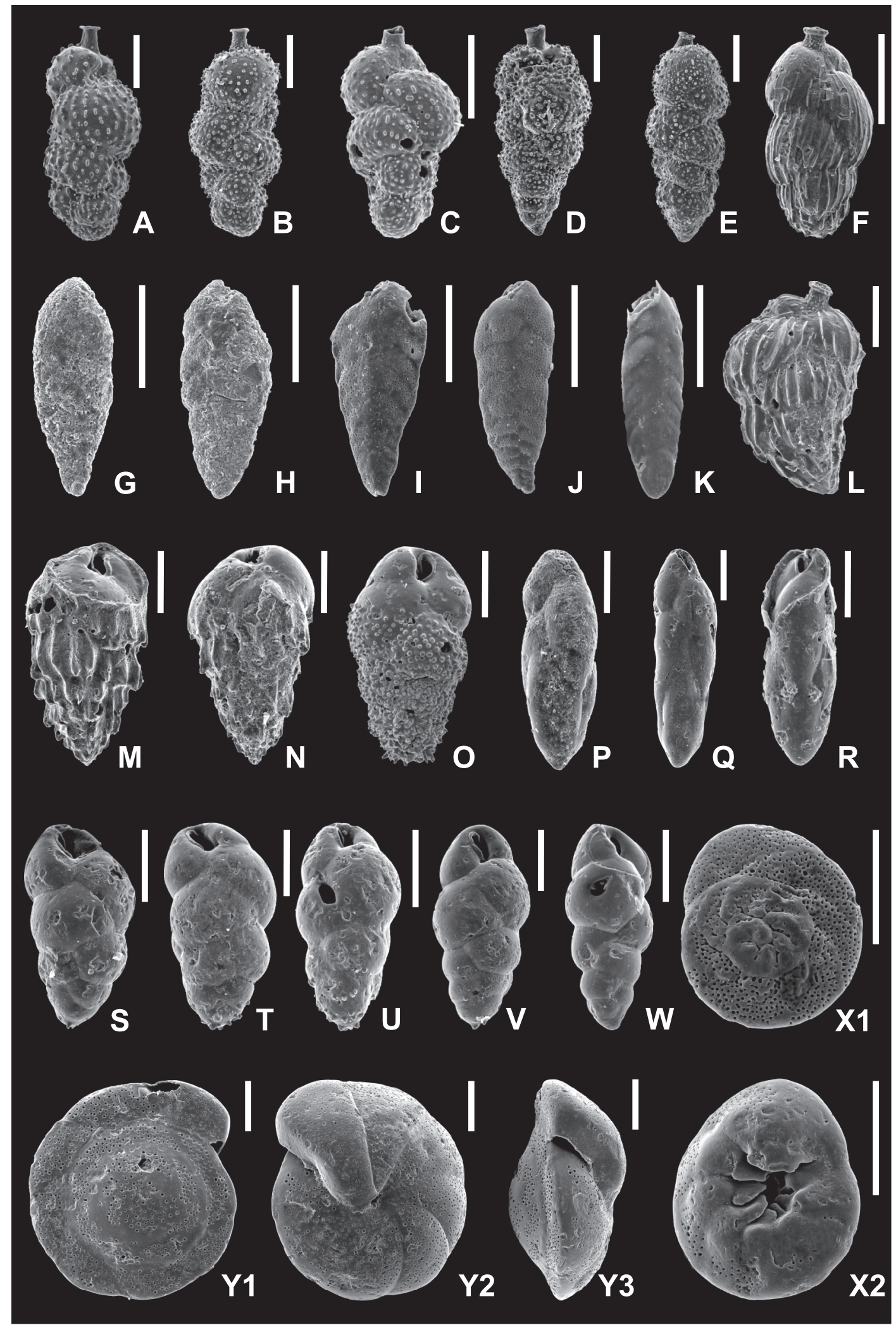

Fig. 7. Benthic foraminifers from the Młyny (Busko) PIG 1 borehole

A-C - Uvigerina aculeata; D, E - Uvigerina hispida; F - Uvigerina semiornata; G - Bolivina sp.; H, I - Bolivina dilatata; J - Bolivina scitula; K - Bolivina cf. dilatata maxima; L - Uvigerina pygmoides; $\mathbf{M}, \mathbf{N}$ - Bulimina striata; $\mathbf{O}$ Bulimina untonsa; P, R - Fursenkoina sp.; Q - Fursenkoina acuta; S-V - Bulimina subulata, W - Bulimina elongata; X1, X2 - Valvulineria complanata; Y1-Y3 - Heterolepa dutemplei; scale bar is $200 \mu \mathrm{m} ; \mathrm{A}-\mathrm{F}, \mathrm{T}, \mathrm{X}$ - sample 7; G, H, P - sample 12; I-K,- sample 9; L-N, Q-S, U-W - sample 6; O - sample 15; Y - sample 26 

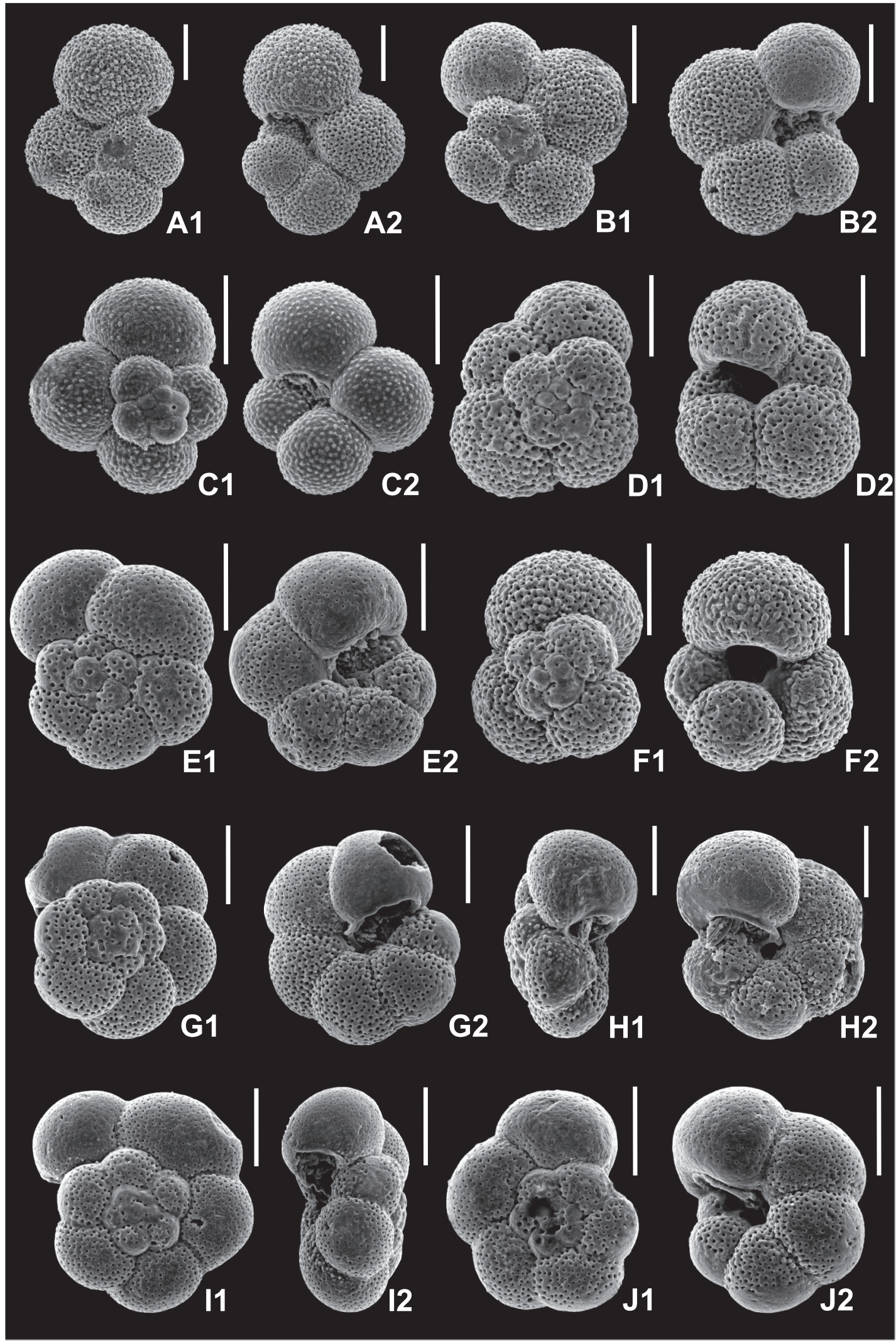

Fig. 8. Planktonic foraminifers from the Młyny (Busko) PIG 1 borehole

A1, A2 - Tenuitella obesa; B1, B2 - Tenuitella subcretacea; C1, C2 - Tenuitellinata juvenilis; D1, D2 - Globoturborotalita sp.; E1, E2 - Paragloborotalia transsylvanica; F1, F2 - Globigerina bulloides; G1, G2, I1, I2 - Paragloborotalia sp.; H1, H2 - Paragloborotalia siakensis; J1, J2 - Paragloborotalia mayeri; scale bar is $100 \mu \mathrm{m}$; A-C, E, G-J - sample 36; D, F sample 7 

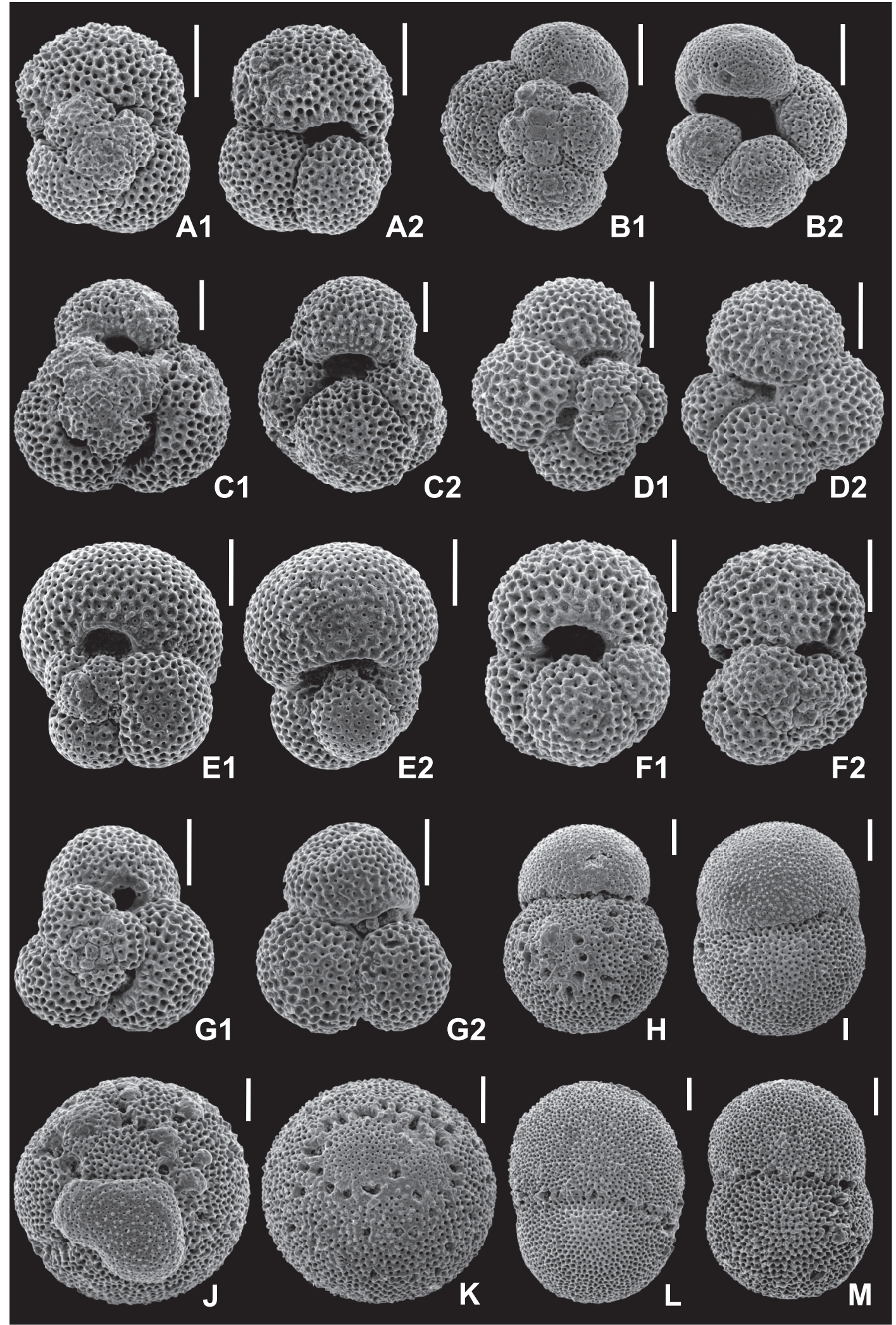

Fig. 9. Planktonic foraminifers from the Młyny (Busko) PIG 1 borehole

A1, A2 - Globigerinoides immaturus; B1, B2 - ?Tenuitella sp.; C1, C2, D1, D2, G1, G2 - Globigerinoides quadrilobatus; F1, F2 - Globigerinoides trilobus; E1, E2 - Globigerinoides primordius; H, I, L, M - Orbulina bilobata; J, K-Orbulina suturalis; scale bar is $100 \mu \mathrm{m}$; A-C, F-sample 24; D, E, G, H, J-L - sample 36; I, M - sample 37 
nificantly, forming from 0 to $85 \%$ of the assemblages. In places their contribution to the assemblages is equal but in most cases their abundances show opposite tendencies: an increase in the abundance of representatives of one genus is accompanied by a decrease in representatives of the second one. In the topmost part of the section Uvigerina almost disappears while Bulimina, mainly $B$. elongata, forms up to $80 \%$ of the assemblage. Bolivina is present in the entire section but only at the level about $2 \mathrm{~m}$ below the gypsum it forms almost $10 \%$ of the assemblage.

The contribution of planktonic foraminifera varies significantly throughout the section. In its lower part the $\mathrm{P} / \mathrm{B}$ ratio is rather high and varies between 60 to $85 \%$. Then, it decreases to $25-40 \%$, and again increases to $80 \%$. In the upper part of the section the $\mathrm{P} / \mathrm{B}$ ratios drop to $2-30 \%$ except for a short interval at $2 \mathrm{~m}$ below the gypsum where it increases to $57 \%$. In the uppermost 0.6-m-thick interval just below the gypsum planktonic foraminifers are very rare.

The lowermost ( $3 \mathrm{~m}$ thick) part of the section yields an abundant warm-water planktonic foraminiferal assemblage composed mainly by orbulinids (i.e., Orbulina suturalis and $O$. bilobata) and Globigerinoides spp. (G. trilobus, G. immaturus, G. primordius and G. bisphericus). Paragloborotalia siakensis and $P$. mayeri are also recorded in this interval. This warm-water planktonic fauna suddenly almost completely disappears $8 \mathrm{~m}$ below the gypsum. Only Globigerinoides trilobus is recorded as a very rare component in planktonic assemblages in the next five metres and its highest occurrence is recorded $3 \mathrm{~m}$ below the gypsum. The succeeding planktonic assemblage is dominated by Globigerina bulloides, which is a cool water index. Cool-temperate species, e.g. Globorotalia bykovae, are subordinate.

\section{LESZCZE}

The studied $1.25 \mathrm{~m}$ thick marls underlying the gypsum yielded very well-preserved foraminiferal assemblages consisting of 47 benthic taxa and 5 planktonic species (Fig. 11 and Appendix 2). The number of benthic species is $23-26$ in the lower $0.8 \mathrm{~m}$ of the section; then it drops to 6 in the sample from the bed underlying the gypsum. The $H(S)$ diversity index varies from 2.3-2.5 in the lower $0.8 \mathrm{~m}$ of the section, but then drops to 1.5 in the sample below the gypsum. Bulimina spp. and Uvigerina spp. dominate among benthic foraminiferal assemblages (Fig. 11), forming 60 to $80 \%$ of the assemblages. Similarly as in the Młyny (Busko) PIG 1 borehole, Bulimina elongata forms $80 \%$ of the assemblage in the sample below the gypsum. Fursenkoina acuta is also an important component of the assemblages in the upper part of the section. Pullenia bulloides, Sphaeroidina bulloides, Melonis pompilioides and Cibicidoides spp. are common. Rare species in this interval are: Hoeglundina elegans, Sigmoilinita tenuis, Laevidentalina spp., Stilostomella, Glandulina hispida, Lobatula lobatula, and Pseudotriplasia elongata - the only agglutinated form in the section.

Planktonic foraminifera form $30-40 \%$ of the foraminiferal assemblages in the lower $0.8 \mathrm{~m}$ of the section. In the $0.4 \mathrm{~m}$ thick interval below the gypsum their contribution to the assemblages drops to $2-5 \%$ (Fig. 11). They consist of Globigerina spp. (mainly G. bulloides). The species Globorotalia bykovae also occurs rarely. The taxonomic composition of these assemblages is indicative of temperate-cold water.

BORKÓW

The studied $2.4 \mathrm{~m}$ thick marls underlying the gypsum showed the presence of 49 benthic foraminiferal species and 11 planktonic ones (see Peryt and Gedl, 2010, appendix 1). Benthic foraminiferal assemblages are almost completely composed of calcareous taxa. Only two agglutinated species (Pseudotriplasia elongata and Vulvulina pectinata) occur sporadically in the lowermost part of the section. The number of benthic species varies from 5 (in the $8 \mathrm{~cm}$ thick interval underlying the gypsum) to 19 (in the lowermost part of the section). The $H(S)$ values vary insignificantly throughout almost the entire section with values between 2.3 to 2.5 . Only in the uppermost $20-\mathrm{cm}$-thick bed just below the gypsum the $H(S)$ values drop to 1 . Benthic foraminiferal assemblages from this section are characterized by high dominance and low diversity (Fig. 12). Bulimina predominates in the section. In its lower part it forms 15 to $30 \%$ of the assemblages and in its upper part the abundance of Bulimina grows rapidly to $80 \%$. Other important contributors are Bolivina, Fursenkoina and Uvigerina. They form at different levels up to $25 \%$ of the assemblages - Bolivina in the lower part, Fursenkoina - in the middle and Uvigerina in the upper part of the section. Hoeglundina elegans appears suddenly and has its acme at 1.8 to $2.4 \mathrm{~m}$ below the gypsum (Fig. 12). In this part of the section it forms up to $40 \%$ of the assemblages. Common are also Globocassidulina oblonga (up to 15\%), Pullenia bulloides, Melonis pompilioides and the oxic marker - Cibicidoides. Elphidium is very rare in the upper part of the section.

Planktonic foraminifera form 15 to $30 \%$ of the assemblages except in two samples where their contribution increases significantly - up to $50 \%$ at $0.5 \mathrm{~m}$ below the gypsum and to $70 \%$ about $2.0 \mathrm{~m}$ below the gypsum. Cold and cool-temperate species are present. The assemblage is dominated by Globigerina bulloides; minor contributors are: G. praebulloides, G. tarchanensis, G. diplostoma, G. concinna, and Globorotalia bykovae.

\section{STABLE ISOPES}

The results of stable isotopic analyses are given in Appendix 3 and Figures 13A-15, but in several cases the measured values were omitted during subsequent interpretations due to the inferred diagenetic alterations that affected both benthic and/or planktonic foraminifers. The reliable data are shown in Figure 13B and are summarized in Table 1.

MŁYNY (BUSKO) PIG 1 BOREHOLE

The benthic carbon isotope record $\left(\delta^{13} \mathrm{C}_{b}\right)$ of the Młyny section shows a small variation throughout the major part of the section, with the $\delta^{13} \mathrm{C}$ values being close to $0 \%$, however, at 8 to $10 \mathrm{~m}$ below the gypsum there is a negative excursion down to $-2.5 \%$ o. Ca. $3.1 \mathrm{~m}$ below the gypsum there is another, smaller excursion (down to $-1.2 \%$ ) followed by an increase (to ca. $-0.3 \% 2.6 \mathrm{~m}$ below the gypsum). The upper $2 \mathrm{~m}$ of the section show variation of $\delta^{13} \mathrm{C}$ values from -0.3 to $-1.5 \%$ (Fig. 14). The planktonic carbon isotope record $\left(\delta^{13} C_{p}\right)$ shows a very similar pattern to the $\delta^{13} \mathrm{C}_{\mathrm{b}}$ record, with most values ranging from 0.5 to $1.0 \%$ and with an excursion ( 8 to $10 \mathrm{~m}$ below the gypsum) down to $-2.9 \%$, and a slight decrease (to $-0.64 \%$ ) in the topmost $2 \mathrm{~m}$ of the section, but with two eminent negative excursions (down to below $-5 \%$ in that part). In addition, there is one positive excursion (to $1.66 \%$ o) $7.7 \mathrm{~m}$ below the gypsum, just above the negative excursion (Fig. 14).

The benthic oxygen isotope record $\left(\delta^{18} \mathrm{O}_{b}\right)$ shows a similar trend of changes as the $\delta^{13} \mathrm{C}_{b}$ record except in the upper part of the section (Fig. 14): below the excursion down to $-2.8 \%$ o the values vary from 1.2 to $1.7 \%$, and above the excursion they are from 1 to $2.6 \%$; the smallest value coincides with the small neg- 


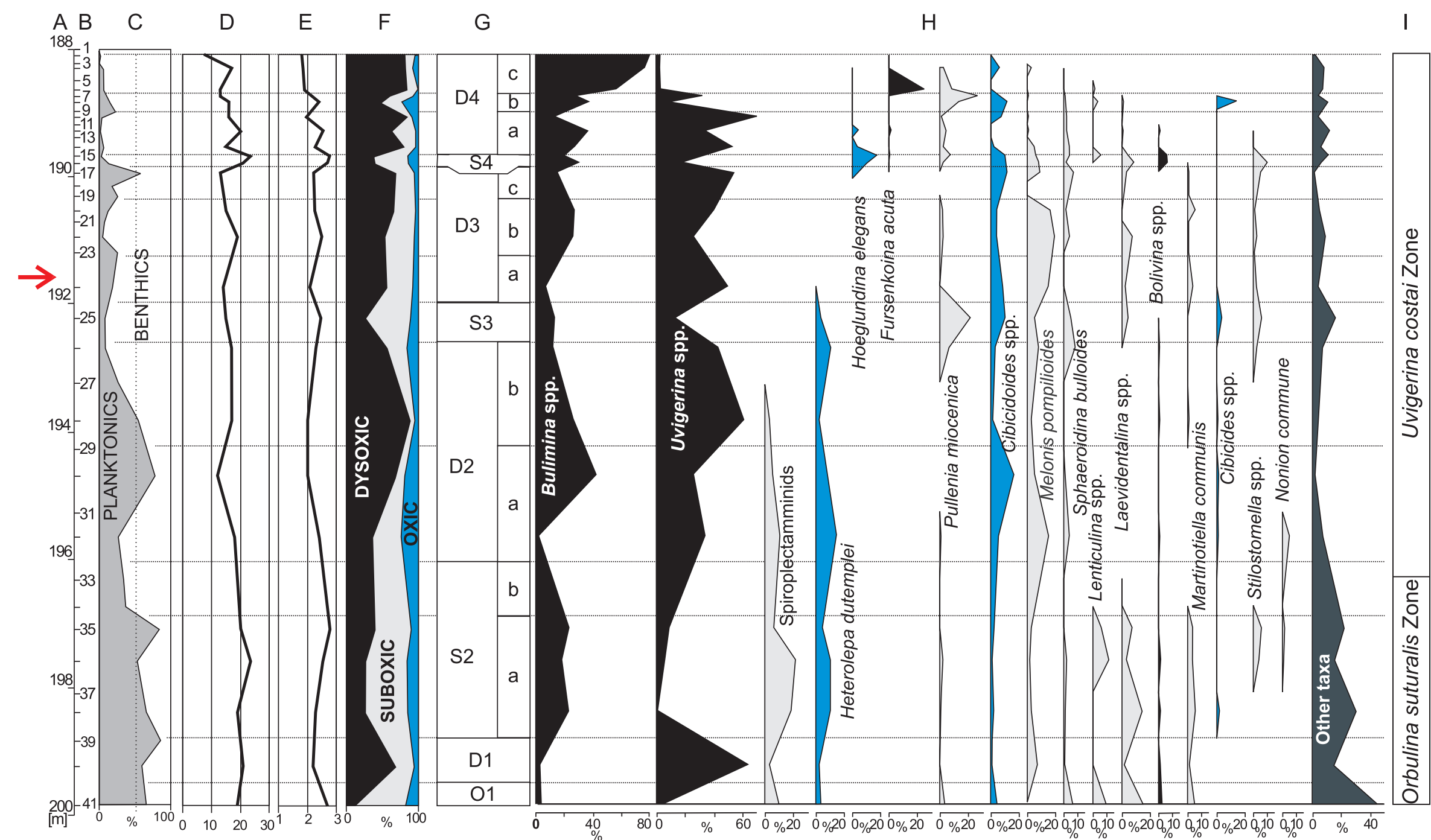

Fig. 10. The Młyny (Busko) PIG 1 borehole section studied

A - depth; B - sample number; C - relative abundance of planktonic and benthic foraminifers; D - simple benthic diversity (number of species); E - H(S) - Shannon-Wevear heterogeneity index; $\mathrm{F}$ - relative abundances of dysoxic, suboxic and oxic taxa; $\mathrm{G}$ - benthic foraminiferal assemblages; $\mathrm{H}$ - relative abundances od dominant and common species or groups of species; the red arrow indicates the position of the tuffite bed described by Bukowski (2011) 
$\mathrm{H}$

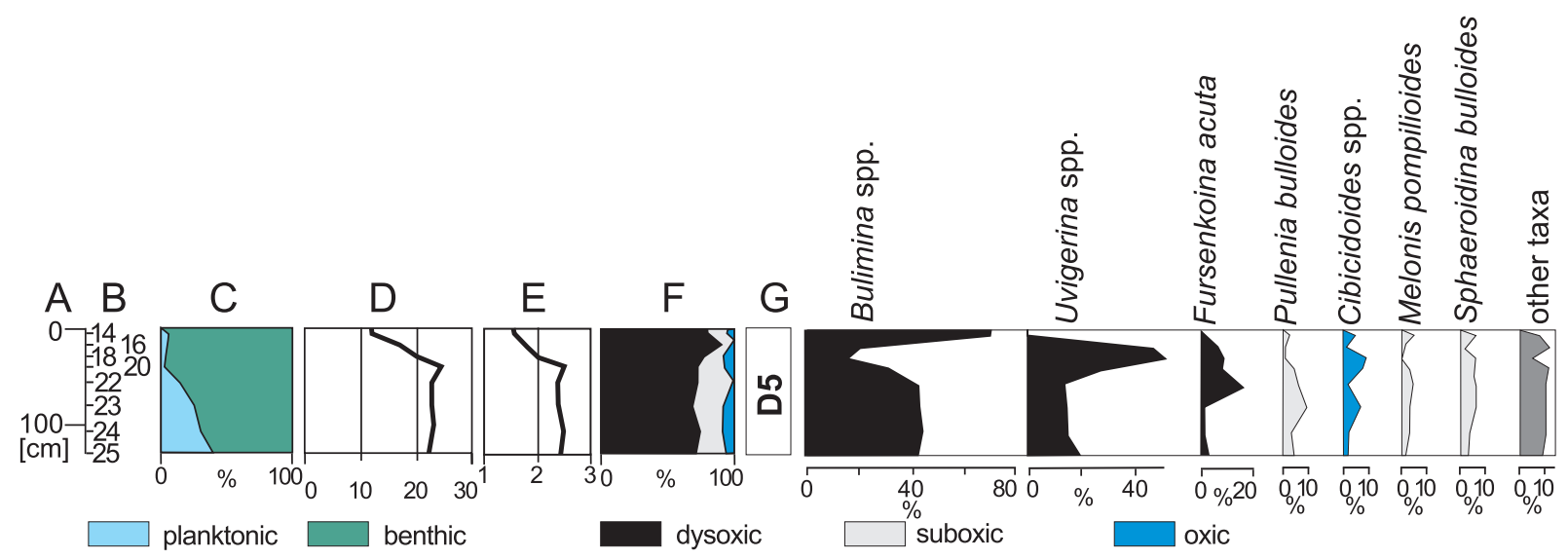

Fig. 11. The Leszcze section studied

$\mathrm{A}-\mathrm{H}-$ for explanations see Figure 10

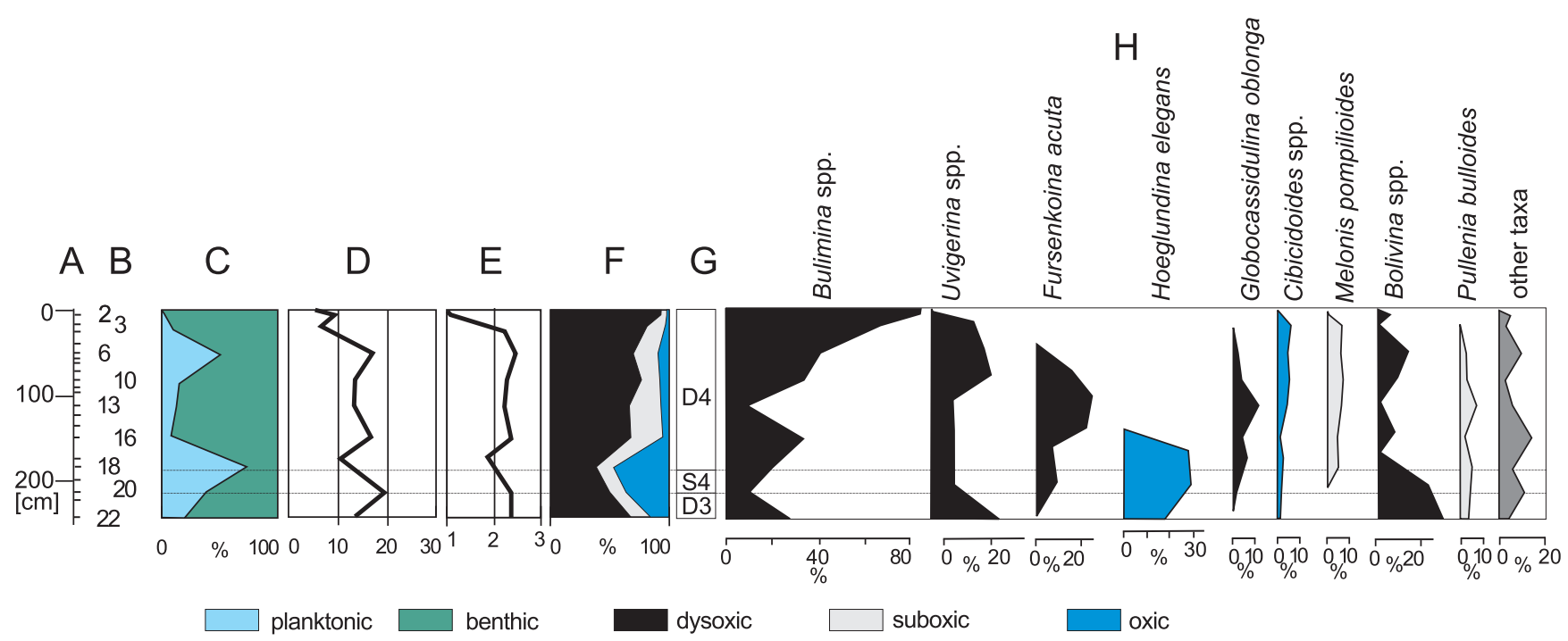

Fig. 12. The Borków section studied

$\mathrm{A}-\mathrm{H}-$ for explanations see Figure 10

ative excursion of the $\delta^{13} C_{b}$ (Fig. 14). The planktonic oxygen isotope record also shows a similar trend of changes as the $\delta^{13} \mathrm{C}_{\mathrm{p}}$ record (Fig. 14).

\section{LESZCZE}

The benthic carbon isotope record $\left(\delta^{13} \mathrm{C}_{b}\right)$ in the Leszcze section shows a gradual decrease, from $0.15 \% 01.3 \mathrm{~m}$ below the gypsum to $-0.85 \%$ o $25 \mathrm{~cm}$ below the gypsum, and then it increases to $0.29 \%$, but just below the gypsum it shows a small fall (to $0.1 \%$ ). The planktonic carbon stable isotope record $\left(\delta^{13} \mathrm{C}_{\mathrm{p}}\right)$ shows a very similar pattern - it decreases from $0.62 \%$ $1.3 \mathrm{~m}$ below the gypsum to $-0.66 \% 25 \mathrm{~cm}$ below the gypsum and then it increases to $0.36 \%$ (there is no slight decrease occurring in the benthic record). The benthic oxygen isotope record $\left(\delta^{18} \mathrm{O}_{\mathrm{b}}\right)$ shows quite a gradual decrease from the base of the section to $0.8 \mathrm{~m}$ below the gypsum, from ca. 3 to $0.5 \%$, and then it gradually increases to $2.72 \%$ at the topmost part, with the only excursion noted at the depth ca. $0.6 \mathrm{~m}$ below the gypsum where the $\delta^{18} \mathrm{O}_{\mathrm{b}}$ values reaches $4.08 \%$ o. The planktonic oxygen isotope record $\left(\delta^{18} \mathrm{O}_{\mathrm{p}}\right)$ shows a very similar trend (except there is no excursion): from $2.15 \%$ at the base to $-0.2 \% 25 \mathrm{~cm}$ below the gypsum, and then to ca. $1.1 \%$ at the top of the section (Fig. 15).

\section{BORKÓW}

The benthic carbon stable isotope record $\left(\delta^{13} \mathrm{C}_{b}\right)$ of the Borków section varies between -0.38 and $0.16 \%$, with a maximum recorded $1.8 \mathrm{~m}$ below the base of the gypsum. Minima are observed 1.6 and $2.0 \mathrm{~m}$ below the gypsum (Fig. 15). Two shifts towards more positive values (by ca. 0.5 and $0.4 \%$; Fig. 15) are 
A

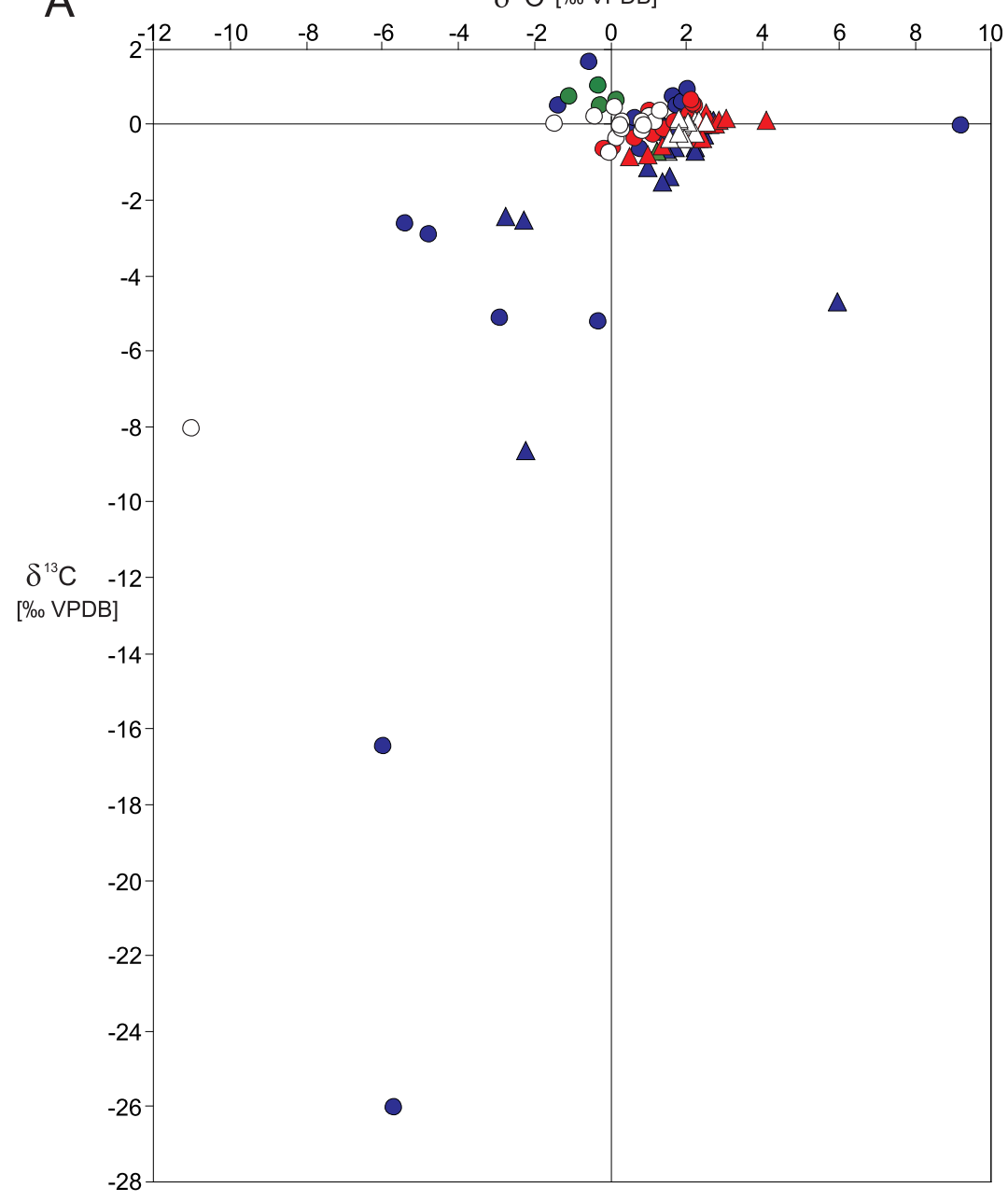

B

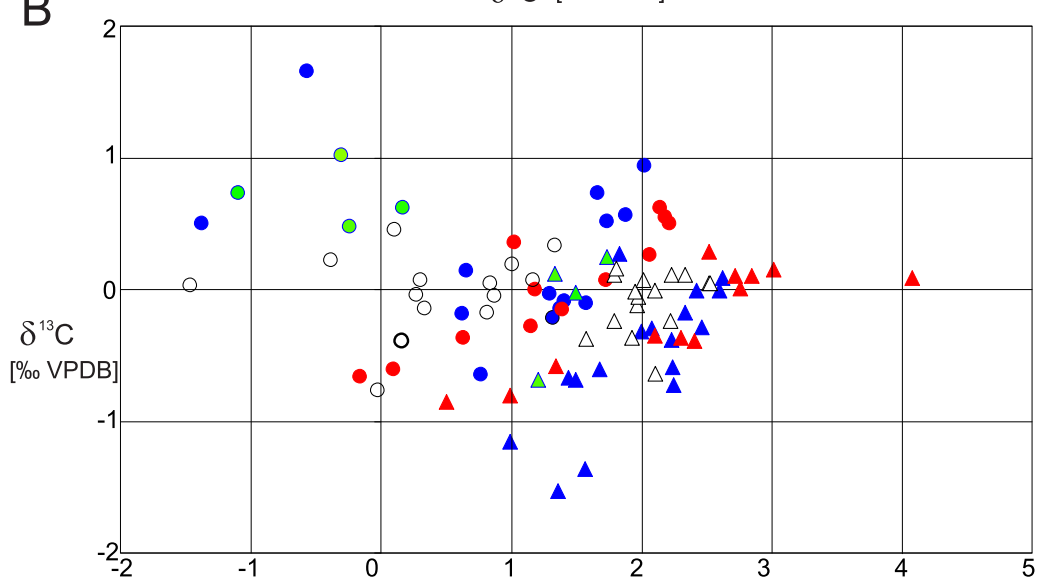

Benthic (mostly Uvigerina):
O Młyny (Busko) PIG 1
Orbulina suturalis Zone
Globigerina:

$\triangle$ Młyny (Busko) PIG 1
Orbulina suturalis Zone
Młyny (Busko) PIG 1
Uvigerina costai Zone

$\Delta$ Młyny (Busko) PIG 1
Uvigerina costai Zone
- Leszcze

O Borków

$\Delta$ Leszcze

$\triangle$ Borków followed by a clear slightly increasing trend and then, in the uppermost part of the section, a decreasing trend of $\delta^{13} \mathrm{C}_{\mathrm{b}}$ values (Fig. 15). The planktonic carbon isotope record $\left(\delta^{13} \mathrm{C}_{\mathrm{p}}\right)$ fluctuates between -0.77 and $0.46 \%$ and has a similar pattern as $\delta^{13} \mathrm{C}_{\mathrm{b}}$ except at $1.8 \mathrm{~m}$ below the gypsum where the negative shift (by $0.8 \%$ ) coincides with the positive shift (by $0.5 \%$ ) of $\delta^{13} \mathrm{C}_{\mathrm{b}}$. The benthic oxygen isotope record shows quite a gradual increase from the base of the section to $0.8 \mathrm{~m}$ below the gypsum, from ca. 1.7 to $2.5 \%$, and then it gradually decreases to $2.0 \%$ in the topmost part. In contrast to the $\delta^{13} \mathrm{C}$ records, the planktonic $\delta^{18} \mathrm{O}$ record shows a very different pattern except for the topmost part of the section (Fig. 15). The $\delta^{18} \mathrm{O}$ values are ranging between -1.47 to 1.34\%o (Fig. 15).

\section{INTERPRETATION AND DISCUSSION}

The taxonomic composition of the foraminiferal assemblages makes it possible to distinguish two foraminiferal zones in the Młyny (Busko) PIG 1 borehole section: the Orbulina suturalis and Uvigerina costai zones (cf. Łuczkowska, 1964; Szczechura, 1984; Gonera et al., 2012; Fig. 10). The boundary between the two zones is located at a depth of $196.3 \mathrm{~m}$. In Leszcze and Borków only the Uvigerina costai Zone was found.

The Orbulina suturalis Zone includes the lower part of the studied section of the Młyny (Busko) PIG 1 borehole comprising the interval contained between samples 41 to 33 (3.5 m thick) with an abundant warm water planktonic foraminiferal assemblage composed mainly of orbulinids and Globigerinoides spp. Rare Globorotalia mayeri and $G$. siakensis are also present. The upper boundary is placed at the level of the highest occurrence of Orbulina suturalis. The lower boundary of the zone has not been detected, due to the presence of Orbulina suturalis in the lowermost sample analysed.

It is commonly supposed that trends in the relative abundance of different foraminiferal taxa are likely to be responses to palaeoenvironmental changes (e.g., Buzas and Gibson, 1969; Murray, 1991, 2006) and it is the organic flux which influences by its amount, kind and quality not only the numbers of individuals but also the species composition of assemblages (Lutze and Coulbourn, 1984; Jorissen et al., 1995; Altenbach et al., 1999; Gooday et al., 2001). A high flux of organic matter to the sea-floor causes low oxygen concentrations within the sediment pore waters because oxygen is used in oxidation of the organic material. Infaunal species dominate in assemblages associated with relatively high organic-carbon fluxes and epifaunal ones in more oligotrophic environments (Corliss and Chen, 1988; Gooday, 1994; Thomas, 1990; Jorissen et al., 


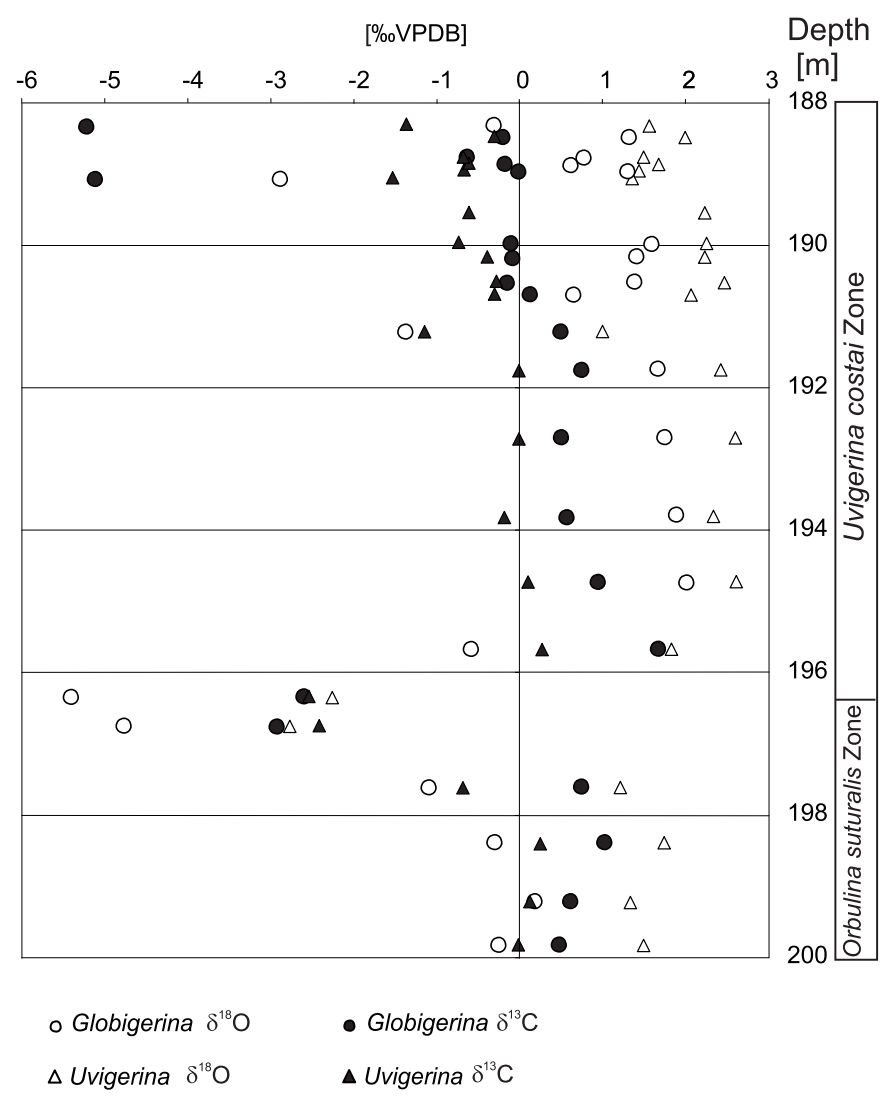

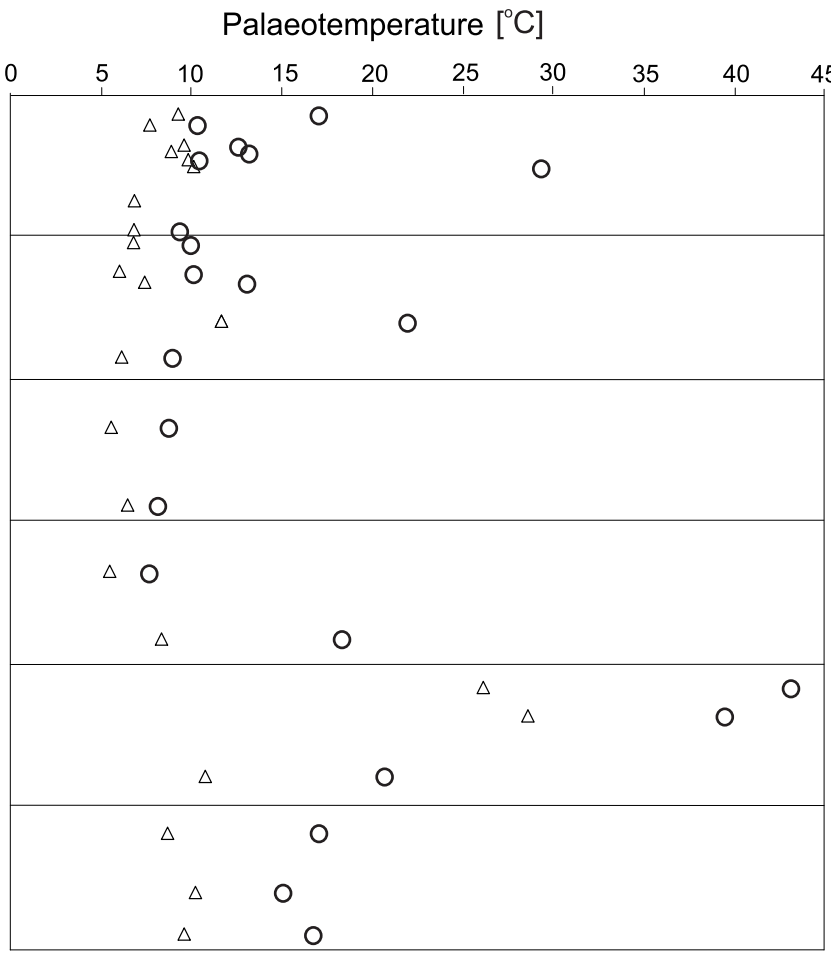

Fig. 14. Benthic and planktonic $\delta^{13} \mathrm{C}$ and $\delta^{18} \mathrm{O}$ isotope records for the Młyny (Busko) PIG 1 borehole section and calculated palaeotemperatures of ambient seawater

1995). Foraminiferal species diversity is much lower in stressed environments and assemblages are characterized by high dominance. The $\mathrm{H}(\mathrm{S})$ values below 2 indicate that the balance in the assemblages is distorted by high dominance of a few stress-tolerant taxa (Buzas and Gibson, 1969).

The benthic foraminiferal successions in the studied sections suggest oxygenation and productivity changes in the Carpathian Foredeep Basin prior to the Badenian salinity crisis. Four intervals of lowered oxygenation and/or elevated organic flux to the sea-floor alternated with intervals where oxygen stress was not so severe, are recognized in the most complete section studied (the Młyny section). Buliminina and Uvigerina are present continuously in the studied interval; in several places they dominate the assemblages; Uvigerina exceeds $60 \%$ while Bulimina even $80 \%$. They are representatives of stress markers, as they are deep infaunally living organisms. In the material studied the deep infauna is represented also by Bolivina spp., Fursenkoina acuta and Globocassidulina oblonga. Of this group only Fursenkoina acuta briefly forms $25 \%$ of the assemblage in the uppermost part of the Uvigerina costai Zone. Oxic species in the studied interval are minor contributors to the assemblages. Their abundance fluctuates between 2 and $20 \%$.

Intervals with benthic assemblages in which stress-tolerant taxa exceed $50 \%$ of the total and with high dominance $[\mathrm{H}(\mathrm{S})$ values are <2.2] are interpreted as having formed under conditions of lowered oxygen levels and high organic flux.

Eight assemblages have been distinguished in the Młyny section (Figs. 10 and 16).
Assemblage $\mathrm{O} 1$ occurs at the base of the section (depth 199.5-200.0 m). The assemblage is relatively highly diversified and with low dominance. The $\mathrm{H}(\mathrm{S})$ value is 2.8 . Spiroplectamminids (Spiroplectinella carinata, Vulvulina pennatula), Martinotiella communis, Melonis pompilioides, Sphaeroidina bulloides, Heterolepa dutemplei, Cibicidoides spp., Hansenisca soldanii, Siphonina reticulata, Stilostomella spp. and nodosariaceans (Laevidentalina elegans, Lenticulina spp.) are the common components of this assemblage. Stress markers (Bulimina costata, Uvigerina aculeata and Bolivina spp.) form only $14.4 \%$, and oxic species (Heterolepa dutemplei, Cibicidoides spp., Sigmoilinita tenuis) $8.6 \%$ of the assemblage. The assemblage indicates a mesotrophic, close to oligotrophic, marine environment.

Assemblage D1 in the 0.7-m-thick interval (depth 198.8 to $199.5 \mathrm{~m}$ ) is dominated by Uvigerina spp., which comprise up to $64 \%$ of the assemblage. Other stress markers: Bulimina ( $B$. costata, B. elongata) and Bolivina (Bol. dilatata, Bol. hebes) form 5\%. Melonis pompilioides, Hansenisca soldanii, nodosariaceans, and spiroplectamminids are common taxa. Oxic taxa form only $3 \%$ of the total assemblage. The $H(S)$ value is 2.2. The high dominance of infaunal forms (Uvigerina, Bulimina, Bolivina), low $\mathrm{H}(\mathrm{S})$ value and low oxic component suggest low oxygen levels at the sea-floor caused by enhanced organic carbon flux and mesotrophic to eutrophic environment.

Assemblage S2 occurs in a 2.7-m-thick interval (depth 196.1 to $198.8 \mathrm{~m}$ ). Two subassemblages (S2a and S2b) are recognized: S2a - with common Bulimina (23\%), spiroplectamminids (20\%), Heterolepa dutemplei $(10 \%)$ and nodosariaceans (up to $19 \%$ ), and the $\mathrm{S} 2 \mathrm{~b}$ subassemblage in which 

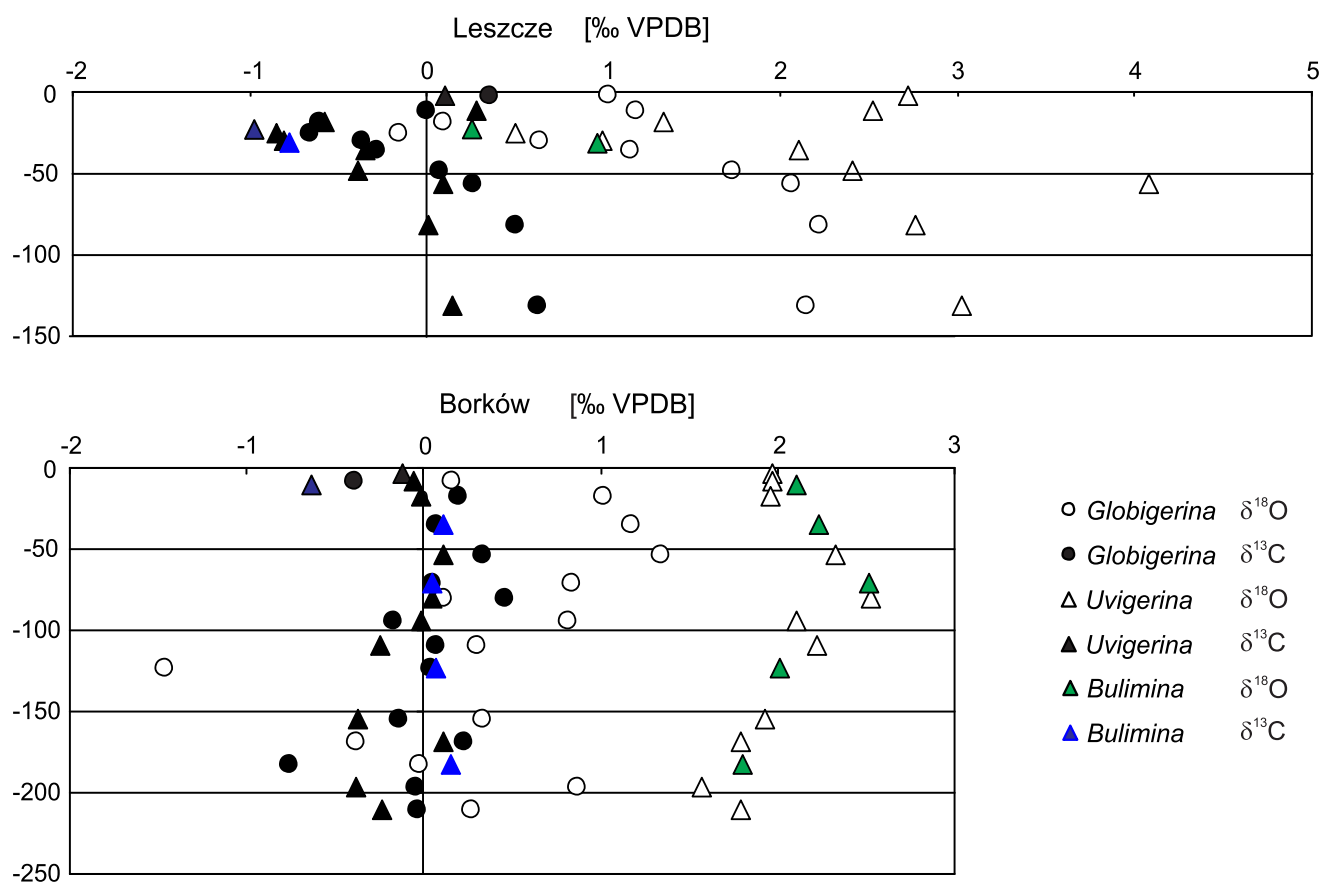

- Globigerina $\delta^{18} \mathrm{O}$

- Globigerina $\delta^{13} \mathrm{C}$

$\triangle$ Uvigerina $\quad \delta^{18} \mathrm{O}$

$\Delta$ Uvigerina $\quad \delta^{13} \mathrm{C}$

$\triangle$ Bulimina $\quad \delta^{18} \mathrm{O}$

$\Delta$ Bulimina $\quad \delta^{13} \mathrm{C}$

Palaeotemperatures for the Leszcze section

$\left[{ }^{\circ} \mathrm{C}\right]$

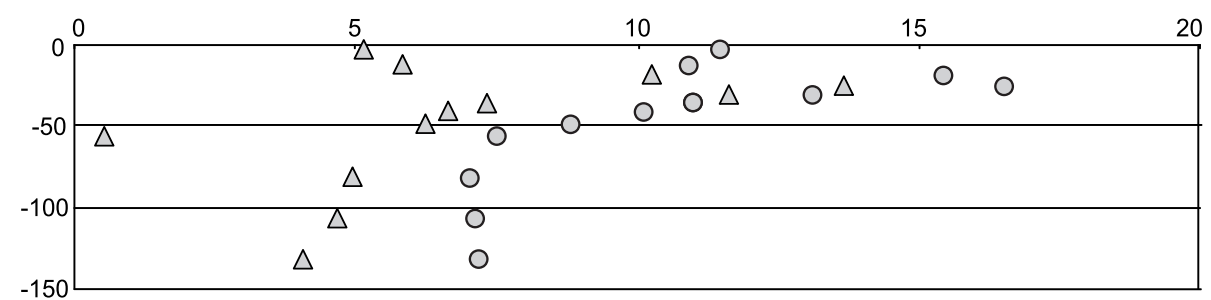

O Globigerina

$\triangle$ Uvigerina and Bulimina

Palaeotemperatures for the Borków section

$\left[{ }^{\circ} \mathrm{C}\right]$

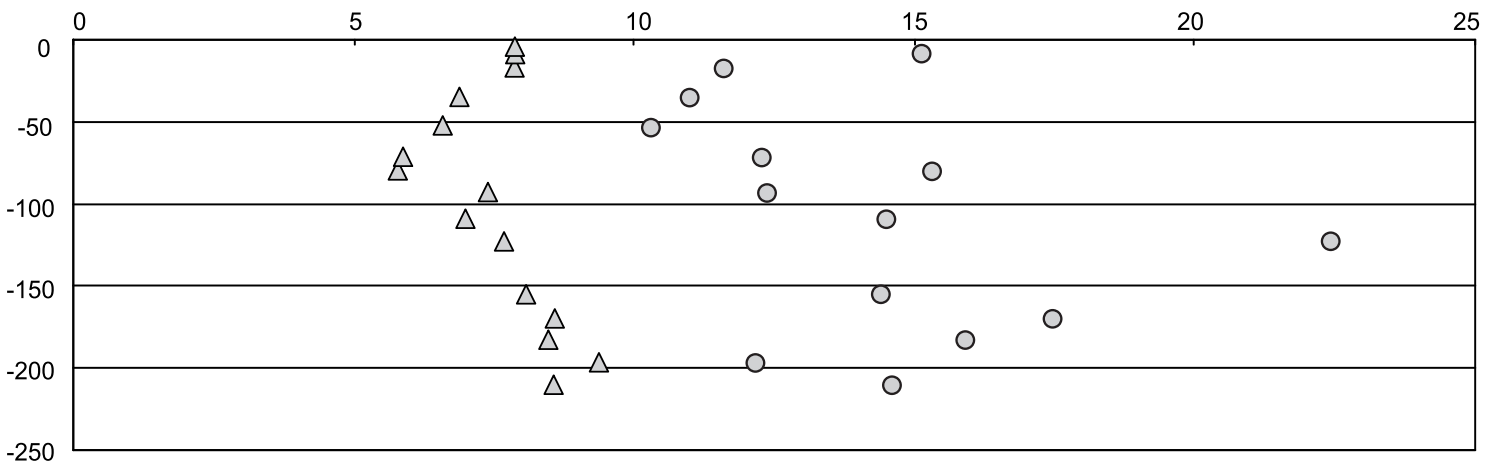

Fig. 15. Benthic and planktonic $\delta^{13} \mathrm{C}$ and $\delta^{18} \mathrm{O}$ isotope records for the Leszcze and Borków sections and calculated palaeotemperatures of ambient seawater

Uvigerina dominates and exceeds 30\%, Melonis pompilioides, Heterolepa dutemplei and spiroplectamminids are common, and nodosariaceans are very rare or absent. Nonion commune in this subassemblage reaches $5 \%$. The $H(S)$ value in assemblage S2 reaches 2.72. Assemblage S2 reflects a return to mesotrophic, close to oligotrophic conditions in surface waters and lowered food supply, which resulted in good oxygenation at the sea-floor and relatively high diversities.

Assemblage D2 in the 3.4-m-thick interval (depth 192.7 and $196.1 \mathrm{~m}$ ) is characterized by high contribution of stress markers which form from 50 to $91 \%$ of the assemblage. The $H(S)$ values are between 2 and 2.2. Two subassemblages (D2a and D2b) are recognized: the D2a subassemblage with Bulimina (42\%) and Uvigerina (24\%). Cibicidoides spp., Heterolepa dutemplei, Melonis pompilioides and Spiroplectinella carinata are common species; oxic species (mainly Cibicidoides spp. and Heterolepa duemplei) form $19 \%$ of the total. The D2b subassemblage is dominated by Uvigerina, which reaches up to $61 \%$; Bulimina is also common (up to $27 \%$ ) and oxic Heterolepa dutemplei $(10 \%)$. The oxic species compose 5 to $16 \%$ of the subassemblage. 
Summary of $\delta^{18} \mathrm{O}$ and $\delta^{13} \mathrm{C}$ statistics for each locality studied

\begin{tabular}{|c|c|c|c|c|c|c|c|c|c|}
\hline \multirow{2}{*}{\multicolumn{2}{|c|}{ Locality }} & \multirow{2}{*}{$\mathrm{n}$} & \multirow{2}{*}{ Taxon } & \multicolumn{3}{|c|}{$\delta^{13} \mathrm{C}[\% \circ \mathrm{VPDB}]$} & \multicolumn{3}{|c|}{$\delta^{18} \mathrm{O}[\% \circ \mathrm{VPDB}]$} \\
\hline & & & & range & mean & SD & range & mean & SD \\
\hline \multirow{6}{*}{$\begin{array}{c}\text { Młyny (Busko) } \\
\text { PIG } 1\end{array}$} & \multirow{2}{*}{ total } & 21 & $U$ & -1.53 to 0.27 & -0.42 & 0.5 & 0.99 to 2.62 & 1.88 & 0.49 \\
\hline & & 18 & G & -0.65 to 1.66 & 0.36 & 0.56 & -1.38 to 2.02 & 0.72 & 1.06 \\
\hline & \multirow{2}{*}{ U.c. Zone } & 17 & $U$ & -1.53 to 0.27 & -0.50 & 0.50 & 0.99 to 2.62 & 1.97 & 0.48 \\
\hline & & 14 & G & -0.64 to 1.66 & 0.26 & 0.60 & -1.38 to 2.02 & 1.03 & 0.96 \\
\hline & \multirow{2}{*}{ O.s. Zone } & 4 & U & -0.69 to 0.25 & -0.09 & 0.41 & 1.21 to 1.74 & 1.44 & 0.23 \\
\hline & & 4 & G & 0.48 to 1.02 & 0.71 & 0.23 & -1.10 to 0.17 & -0.37 & 0.53 \\
\hline \multirow{2}{*}{\multicolumn{2}{|c|}{ Leszcze }} & 9 & $U$ & -0.85 to 0.15 & -0.22 & 0.39 & 0.5 to 4.08 & 2.24 & 1.11 \\
\hline & & 12 & $G$ & -0.66 to 0.62 & 0.02 & 0.45 & 0.16 to 2.21 & 1.3 & 0.81 \\
\hline \multirow{2}{*}{\multicolumn{2}{|c|}{ Borków }} & 11 & $U$ & -0.38 to 0.11 & -0.10 & 0.18 & 1.57 to 2.53 & 2.06 & 0.27 \\
\hline & & 14 & $G$ & -0.76 to 0.46 & -0.01 & 0.31 & -1.47 to 1.34 & 0.38 & 0.73 \\
\hline \multirow{2}{*}{\multicolumn{2}{|c|}{ TOTAL }} & 44 & $U$ & & -0.31 & 0.43 & & 1.99 & 0.64 \\
\hline & & 44 & G & & 0.15 & 0.49 & & 0.77 & 0.95 \\
\hline
\end{tabular}

U - Uvigerina; G - Globigerina; U.c. Zone - Uvigerina costai Zone; O.s. Zone - Orbulina suturalis Zone

The foraminiferal record from the 8-m-thick marls underlying the gypsum indicates a longer period of high primary productivity and eutrophication of surface waters interrupted by a few short lasting periods with a return to mesotrophic, nearly oligotrophic conditions.

Assemblage D2 represents period of high primary productivity and low bottom-water oxygen content. The high dominance of Uvigerina and Bulimina and low content of oxic species confirm unfavourable conditions for the epifauna. The dominance of foraminiferal assemblages firstly by Bulimina over Uvigerina and then by Uvigerina over Bulimina may be probably explained by the different nutritional requirements of the two groups.

Assemblage $\mathrm{S} 3$ in the 0.7 -m-thick interval at 192.0 to $192.7 \mathrm{~m}$ depth, is relatively highly diversified and shows low dominance. Stress markers do not reach $30 \%$. Oxic species form $23 \%$ of the assemblage. Abundant is Pullenia (21\%); common - Melonis pompilioides (5\%). After a longer absence Laevidentalina spp. and Stilostomella spp. reappear in this assemblage. The $H(S)$ value is 2.52 . The low contribution of stress markers, low dominance, and relatively high diversity suggest mesotrophic conditions.

Assemblage D3 recorded in the 2-m-thick interval at a depth of 190.0 to $192.0 \mathrm{~m}$ is subdivided into three subassemblages: D3a, D3b and D3c. Subassemblage D3a (in the lower $0.7 \mathrm{~m}$, at 191.3 to $192.0 \mathrm{~m}$ depth) is dominated by Uvigerina which reaches $50 \%$; Bulimina forms only $6 \%$. Suboxic Melonis pompilioides comprises up to $15 \%$ of the subassemblage. Oxic species are less common. Cibicidoides spp. do not exceed $8 \%$. The $H(S)$ value drops to 2 . Subassemblage D3b (in the 0.9-m-thick interval at 190.4 to $191.3 \mathrm{~m}$ depth) differs from the previous subassemblage by the decrease in the abundance of Uvigerina. In subassemblage D3b, Uvigerina and Bulimina contribute in similar numbers and form $53 \%$ of the assemblage. Melonis pompilioides is other common species reaching $19 \%$. Oxic markers are not abundant and form only $5 \%$ of the subassemblage. The $H(S)$ value is 2.5 . Subassemblage D3c in the upper $0.4 \mathrm{~m}$, at 190.0 to $190.4 \mathrm{~m}$ depth, is dominated by Uvigerina which forms up to $53.5 \%$ of the subassemblage. Bulimina does not exceed 15\%. Melonis pompilioides, Sphaeroidina bulloides, Stilostomella spp. are common taxa. Oxic species (mainly Cibicidoides spp.) form 6\% of the total. The $H(S)$ value is 2.2. The subassemblage D3c is recognized in the lowermost 0.3-m-thick part of the Borków section. At this site, however, Bolivina, along with Bulimina and Uvigerina, is an important contributor to the assemblage; its content exceeds $20 \%$. Assemblage D3 reflects a longer period of eutrophic, close to mesotrophic conditions in surface waters and lowered oxygenation at the sea-floor.

Assemblage S4 occurs in the 0.4-m-thick interval (at 189.6 to $190.0 \mathrm{~m}$ depth) where stress markers form only $30 \%$. The oxic species (mainly Hoeglundina elegans and Cibicidoides spp.) are present in similar proportions, forming up to $31 \%$ of the assemblage. Melonis pompilioides, Lenticulina, Nodosaria, and Stilostomella are also common in this assemblage. The $\mathrm{H}(\mathrm{S})$ value is 2.8. In the Borków Quarry, assemblage S4 is recorded 1.6 to $2.0 \mathrm{~m}$ below the gypsum. Assemblage S4 with its low contribution of stress markers, low dominance and relatively high diversity indicates a short-lived return to mesotrophic, close to oligotrophic, conditions.

Assemblage D4 recorded in the 1.6-m-thick interval at 188.0 to $189.6 \mathrm{~m}$ depth is subdivided into three subassemblages: $\mathrm{D} 4 \mathrm{a}$, $\mathrm{D} 4 \mathrm{~b}$ and D4c. Subassemblage D4a (in the 0.6-m-thick interval, at 189.0 to $189.6 \mathrm{~m}$ depth) is characterized by benthic foraminiferal assemblages where the contribution of stress markers is very high and varies insignificantly (75 to $83 \%)$. The $H(S)$ values are between 1.9 and 2.6. Uvigerina and Bulimina dominate the assemblages. Uvigerina forms between 33 and $60 \%$ of the assemblages, and Bulimina 13 to $37 \%$. Oxic species are minor contributors and do not exceed $7 \%$ of the assemblages. Subassemblage D4b occurs in the 0.3-m-thick interval (at 188.7-189.0 m depth) where stress markers form ca. 50\% Bulimina-37\%, Uvigerina-9\%); Pullenia miocenicais abundant and reaches $25 \%$ in this assemblage. Oxic markers (mainly Cibicidoides and Cibicides) form $24 \%$ of assemblage. The $H(S)$ values are between 2 and 2.4. Subassemblage D4c occurs in the uppermost 0.7-m-thick interval (at 188.0-188.7 m depth) just below the gypsum and is dominated by Bulimina; its contribution varies from 57 to $80 \%$, while Uvigerina becomes a minor component and drops to less than 2\%. Fursenkoina acuta reaches 25\% in the lower part. The $\mathrm{H}(\mathrm{S})$ values are 1.8 to 1.9 . 


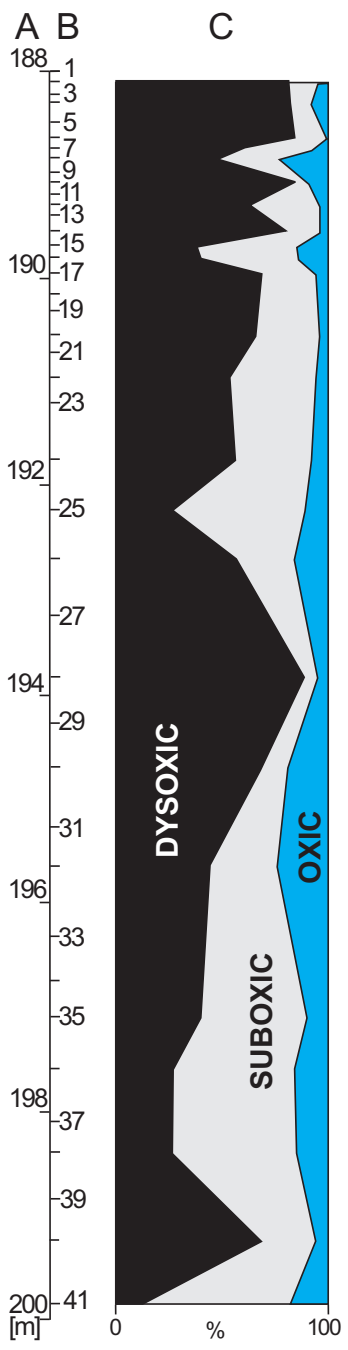

D $\quad E$

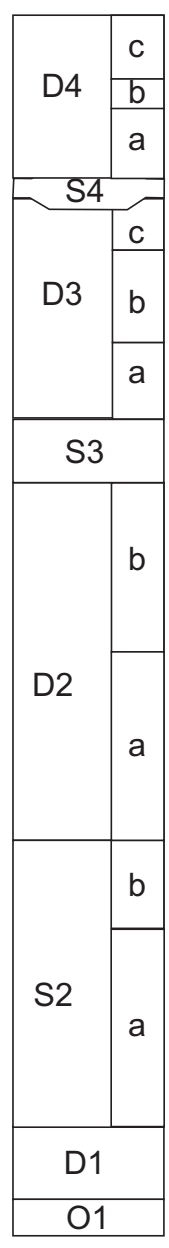

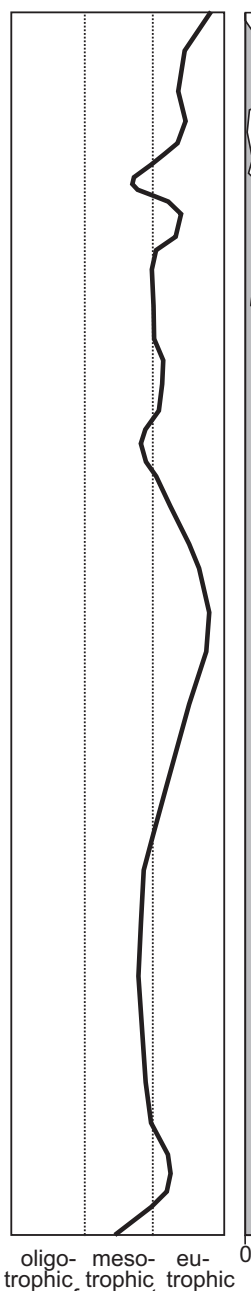

$\mathrm{F}$

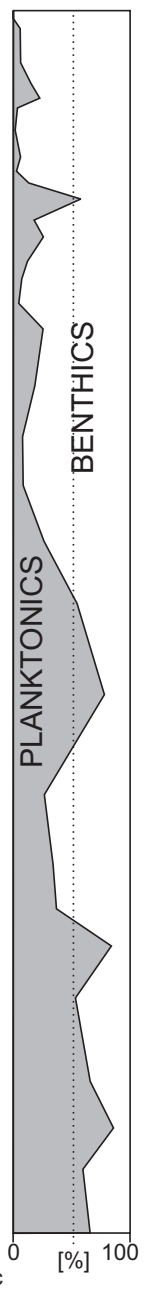

G

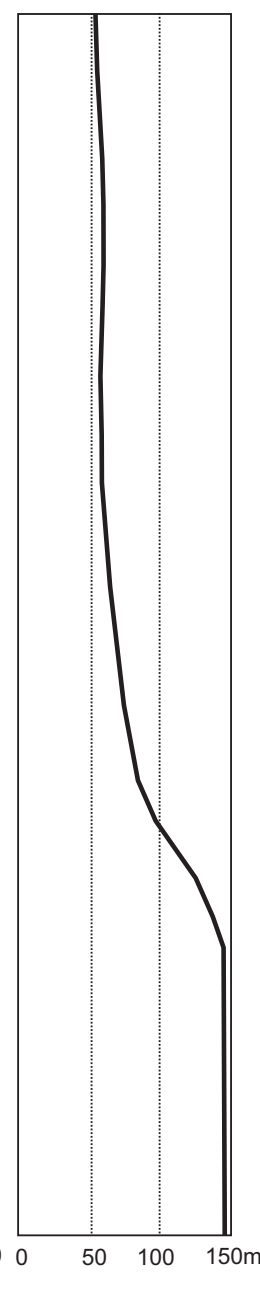

$\mathrm{H}$

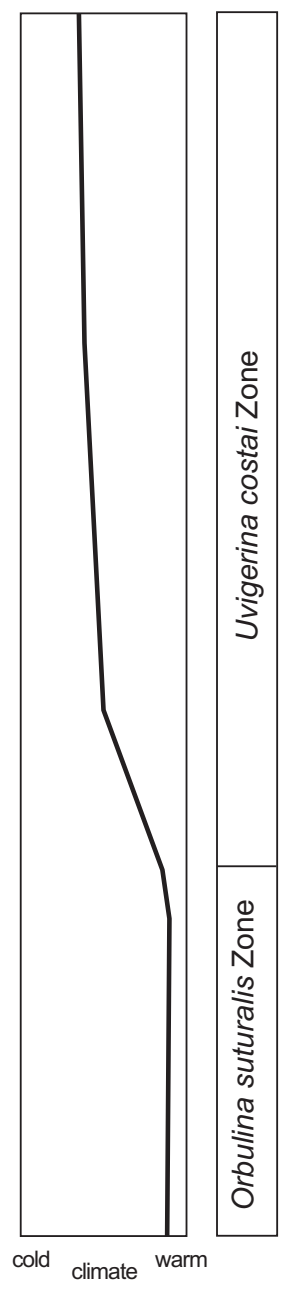

Fig. 16. Summary of environmental changes prior to the Badenian Salinity Crisis in the northern part of the Polish Carpathian Foredeep Basin inferred from changes in foraminiferal assemblages in the Młyny (Busko) PIG 1 borehole

A - depth; B - sample number; C - proportion of dysoxic, suboxic and oxic forms in benthic foraminiferal assemblages; D benthic foraminiferal assemblages (see the text for explanation); $E$ - relative changes in eutrophication of surface waters; $F$ abundance fluctuation of planktonic and benthic forms in foraminiferal assemblages; $\mathrm{G}-$ sea level changes; $\mathrm{H}-\mathrm{climatic}$ changes; I - foraminiferal zones

Assemblage D4 occurs in a 1. 6-m-thick marl underlying the gypsum in the Borków Quarry and in a 1.2-m-thick marl below the gypsum outcropping in the Leszcze Quarry.

Assemblage D4 reflects again a period with high primary productivity and eutrophic conditions in surface waters and highly dysoxic waters at the seafloor. The youngest subassemblage D4c with very high dominance of Bulimina indicates probably not only very low oxygen levels at the sea-floor causing stress for benthic life, but probably also increased salinity as Bulimina is tolerant of both dysoxia and high bottom-water salinity (Verhallen, 1991). The $H(S)$ diversity index is used as a measure of the stability of the environment. In open-marine outer shelf to slope environments, the $\mathrm{H}(\mathrm{S})$ value is about 3 (Murray, 1991; Drinia et al., 2007). Decreasing values of $\mathrm{H}(\mathrm{S})$ suggest increasing environmental stress and increased dominance and low diversity in populations. The $H(S)$ values $<2$ indicate a high dominance of a few tolerant taxa. In upwelling areas with high primary productivity foraminiferal diversity is reduced. The depth in the sediment down to which organisms can live is determined by oxygen availability, and in the presence of oxygen, the vertical distribution of organisms is controlled by food availability (Jorissen et al., 1992). High rates of primary production at the surface lead to anaerobic bacterial blooms in the oxygen minimum zone of mid-waters and on the sea-floor beneath. In eutrophic regions deep infaunal species dominate assemblages under dysaerobic conditions (Corliss and Chen, 1988; Jorissen et al., 1995). Bulimina, Bolivina, Uvigerina are calcareous foraminifers that proliferate in such environments (Bernhard, 1986; Perez-Cruz and MachainCastillo, 1990). Fluctuations of abundances of stress markers in the assemblages reflect changes in oxygenation and the preservation of organic matter at the sea-floor. Assemblages D1, D2-D4 and with low values of $\mathrm{H}(\mathrm{S})(<2.2)$ represent periods with high organic flux and dysoxic conditions at the sea-floor. 
The Bulimina and Uvigerina groups are taxa with high tolerance to dysoxia and increased salinity (van der Zwaan, 1982, 1983; Lutze and Colbourn, 1984; Verhallen, 1991; Jorissen et al., 1992; Loubère, 1994, 1996). However, alternations of peak abundances of the two groups may be related to the amount, kind and quality of organic matter input to the sea-floor (Lutze and Coulbourn, 1984; Jorissen et al., 1995; Altenbach et al., 1999; Gooday et al., 2001; Peryt et al., 2002) especially if the two groups have specific and different nutritional requirements (van der Zwaan, 1982).

Assemblages S2-S5 characterize periods of ameliorated oxygenation conditions at the sea floor (suboxic environments). In these assemblages taxa tolerant for suboxic environments form 37 to $50 \%$ of the assemblages, and the $\mathrm{H}(\mathrm{S})$ value is $>2.2$. Spiroplectamminids, Lenticulina, Laevidentalina, Pullenia, Melonis pompilioides, Sphaeroidina bulloides, Nonion commune are common; in places they form up to $25 \%$ of the assemblage (e.g., Pullenia miocenica at depths of 192.2 and $188.65 \mathrm{~m}$ ). Oxic species represented by Heterolepa dutemplei, Cibicidoides spp. and Hoeglundina elegans rarely reach $20 \%$.

Assemblage $\mathrm{O} 1$ is composed of several species that are equally abundant. The $H(S)$ values are $>2.8$. Dysoxic taxa form only $13.5 \%$ of this assemblage. Oxic species form $12 \%$. The largest component consists of species that live as shallow infauna and are tolerant to suboxic environments. They form up to $75 \%$ of the assemblage. This assemblage reflects the period of highest oxygenation level at the sea-floor in the entire studied section.

Planktonic foraminifera are present throughout the Młyny section except in the topmost $0.2 \mathrm{~m}$ thick bed below the gypsum where this group is practically absent. In the lower part of the section (i.e., most of the Orbulina suturalis Zone) the P/B ratio values are high $(60-85 \%)$. At the Orbulina suturalis/Uvigerina costai boundary interval the P/B decreases to $30-50 \%$ and again increases up to $80 \%$ in the middle part of the Uvigerina costai Zone. The upper part of the zone is characterized by low $\mathrm{P} / \mathrm{B}$ values.

Warm-water planktonic foraminifera (i.e. Orbulina and Globigerinoides) dominate planktonic foraminiferal assemblages in the Orbulina suturalis Zone. Minor contributors to the assemblages are Paragloborotalia mayeri and $P$. siakensis - also indicators of oligotrophic warm-waters. Planktonic foraminiferal assemblages from the Uvigerina costai Zone are characterized by the high dominance of Globigerina bulloides.

Globigerinoides is a surface-dweller common in warm, oligotrophic waters of the mixed layer with highest abundances in regions where there is a permanent vertical stratification of the water column (Hemleben et al., 1989; Di Stefano et al., 2010). Orbulina - an intermediate water dweller living mainly at $50-100 \mathrm{~m}$ - is usually associated with relatively warm and oligotrophic surface waters (Hemleben et al., 1989; Armstrong and Brasier, 2005). Globigerina bulloides is a mixed-layer, cold-water dweller adapted to more eutrophic waters, tolerant for a wide range of typical oceanic salinities (Pujol and Vergnaud-Grazzini, 1995; Majewski, 2003; Majewski and Bohaty, 2010). Globorotalia is a deeper water dweller living mainly below $100 \mathrm{~m}$, adapted to cooler, more eutrophic waters (Armstrong and Brasier, 2005).

The upsection decrease in the proportion of planktonic foraminifers reflects the shallowing of the basin accompanied by a decrease in the temperature gradient between the upper (warmer) and deeper (colder) waters. The replacement of intermediate warm water planktonic foraminiferal assemblages by assemblages dominated by Globigerina (mainly G. bulloides) is related to the Middle Miocene climate transition. This event was widely recorded in the middle Badenian of the Paratethys area (e.g., Gonera et al., 2000; Gonera, 2001; Hudáčková and Spezzaferri, 2002; Böhme, 2003; Jiménez-Moreno et al., 2005; Báldi, 2006; Harzhauser and Piller, 2007). It should be mentioned that already Szczechura (1982) interpreted the replacement of the assemblage of planktonic foraminifers with Globigerinoides spp. and orbulinids by the assemblage with Globigerina spp. (mainly G. bulloides) and Globorotalia bykovae as due to the climate cooling; consequently, she distinguished the occurrence of two ecozones below the evaporites: a Globigerinoides ecozone and a Globigerina ecozone.

$\delta^{13} \mathrm{C}$ and $\delta^{18} \mathrm{O}$ values of foraminifers are commonly applied for palaeoenvironmental interpretations of the Central Paratethys in the Badenian (e.g., Durakiewicz et al., 1997; Gonera et al., 2000; Báldi, 2006; Báldi and Hohenegger, 2008; Kováčová and Hudáčková, 2009; Kováčová et al., 2009; Peryt and Gedl, 2010; Bukowski, 2011; Holcová and Demeny, 2012; Gonera and Bukowski, 2012). The earlier studies have shown large variabilities which, as indicated by Holcová and Demény (2012), indicate sample inhomogeneity even in well-preserved foraminiferal samples, due to primary environmental variation and postmortem mixing of tests of various populations and sources. Total foraminiferal samples reported in this paper had a mean $\delta^{13} \mathrm{C}$ value ca. $0 \%$ o $(-0.31 \pm 0.43 \%$ for Uvigerina and $0.15 \pm 0.49 \%$ for Globigerina). Accordingly, the $\delta^{13} \mathrm{C}$ values of Uvigerina are lower than those of Globigerina (Table 1) which is the normal case, since an increased flux of organic matter to the sea-floor results in an increase in light carbon in infaunal benthic foraminifera (McCorkle et al., 1990); hence bottom waters contain depleted $\delta^{13} \mathrm{C}$ (Broecker and Peng, 1982). The same is characteristic for the Upper Silesia Basin where Gonera and Bukowski (2012) reported a similar mean value for Uvigerina $(0.07 \pm 0.11 \%$ in IIC and $-0.42 \pm 0.46 \%$ in IID) and a slightly higher mean value for Globigerina $(0.53 \pm 0.28 \%$ for IIC and $0.29 \pm 0.4 \%$ o for IID); very similar values were recorded in the Młyny (Busko) PIG 1 borehole (Table 1). However, this is not the case in Moravia (Holcová and Demeny, 2012, fig. 11) and Vienna Basin (Kováčová and Hudáčková, 2009; Kováčová et al., 2009) where Globigerina has lighter $\delta^{13} \mathrm{C}$ values than the benthic taxa. The foraminiferal samples from the Połaniec Trough had a mean $\delta^{18} \mathrm{O}$ value of $1.99 \pm 0.64 \%$ for Uvigerina and $0.77 \pm 0.95 \%$ for Globigerina. In Upper Silesia, Uvigerina shows a similar mean $\delta^{13} \mathrm{O}$ value $(2.06 \pm 0.72 \%$ for IIC and 2.54 $\pm 0.27 \%$ for IID; Gonera and Bukowski, 2012). In contrast, Globigerina shows a slightly higher mean $\delta^{13} \mathrm{O}$ value in Upper Silesia $(1.28 \pm 1.11 \%$ in IIC and $1.88 \pm 0.19 \%$ in IID; Gonera and Bukowski, 2012) than in the Młyny (Busko) PIG 1 section (Table 1). The average $\delta^{18} \mathrm{O}$ value of Globigerina in the Vienna Basin (0.25\%o according to Kováčová and Hudáčková, 2009) is lower than in the Młyny (Busko) PIG 1 section and Upper Silesia; a still lower value (ca. $-1 \%$; see Holcová and Demény, 2012, fig. 11) is recorded in Moravia.

For calculation of palaeotemperatures, various equations are used but all generally follow the original equation established by Epstein et al. (1953). However, due to various corrections the final temperature values can differ substantially (Appendix 4) although the trends of temperature changes based on calculations with various equations remain stable. All temperature equations take into account the isotopic composition of the seawater where the carbonate was precipitated, which is unknown. In addition, the possible effect of salinity increase has to be taken into account when interpreting the fossil records in the intervals prior to evaporite deposition (see discussion in Peryt and Gedl, 2010). For simplicity it was accepted, during the first approximation, that the Paratethys was an epicontinental sea of slightly elevated seawater salinity $\left(\delta^{18} \mathrm{O}_{\text {water }}=0.1 \% \mathrm{SMOW}\right.$ as 
Range of and mean palaeotemperatures for Uvigerina and Globigerina assuming that $\delta^{18} O_{\text {water }}$ was $-1 \%$, $0 \%, 0.1 \%$ and $+1 \%$.

\begin{tabular}{|c|c|c|c|c|c|}
\hline \multirow{2}{*}{ Locality } & \multirow{2}{*}{ Taxon } & \multicolumn{4}{|c|}{ Range of palaeotemperatures $\left[{ }^{\circ} \mathrm{C}\right]$ assuming that $\delta^{18} \mathrm{O}_{\text {water }}$ was } \\
\hline & & $-1 \%$ SMOW & $0 \%$ SMOW & $0.1 \%$ SMOW & $1 \%$ SMOW \\
\hline \multirow{2}{*}{$\begin{array}{c}\text { Młyny (Busko) } \\
\text { PIG } 1\end{array}$} & $U$ & 1.8 to 7.4 & 5.2 to 11.3 & 5.5 to 11.7 & 11.2 to 15.4 \\
\hline & G & 3.8 to 17.0 & 7.3 to 21.5 & 7.7 to 22.0 & 11.2 to 26.3 \\
\hline \multirow{2}{*}{ Leszcze } & $\mathrm{U}$ & -2.6 to 9.3 & 0.3 to 13.3 & $0.6-13.7$ & 3.6 to 17.5 \\
\hline & G & 3.1 to 10.6 & 6.6 to 14.7 & 7.0 to 15.1 & 10.4 to 19.1 \\
\hline \multirow{2}{*}{ Borków } & $\mathrm{U}$ & 2.1 to 5.3 & 5.5 to 9.0 & 5.8 to 9.4 & 9.2 to 13.0 \\
\hline & G & 6.2 to 17.4 & 9.9 to 22.0 & 10.3 to 22.4 & 13.9 to 26.8 \\
\hline \multirow{2}{*}{ TOTAL } & $\mathrm{U}$ & 1.7 to 5.8 & 5.1 to 9.6 & 5.4 to 9.9 & 8.7 to 13.6 \\
\hline & G & 4.8 to 12 & 8.4 to 16.1 & 8.8 to 16.6 & 12.4 to 20.6 \\
\hline & & \multicolumn{4}{|c|}{ Mean palaeotemperatures $\left[{ }^{\circ} \mathrm{C}\right]$ assuming that $\delta^{18} \mathrm{O}_{\text {water }}$ was } \\
\hline & & $-1 \%$ SMOW & 0\% SMOW & $0.1 \%$ SMOW & $1 \%$ SMOW \\
\hline \multirow{2}{*}{$\begin{array}{c}\text { Młyny (Busko) } \\
\text { PIG } 1\end{array}$} & $U$ & 4.3 & 7.8 & 8.2 & 11.7 \\
\hline & G & 8.5 & 12.4 & 12.8 & 16.6 \\
\hline \multirow{2}{*}{ Leszcze } & $\mathrm{U}$ & 2.8 & 6.3 & 6.7 & 10.1 \\
\hline & G & 6.3 & 10.1 & 10.5 & 14.1 \\
\hline \multirow{2}{*}{ Borków } & U & 3.6 & 7.2 & 7.6 & 11 \\
\hline & G & 9.8 & 13.8 & 14.2 & 18.1 \\
\hline \multirow{2}{*}{ TOTAL } & U & 3.7 & 7.3 & 7.6 & 11.1 \\
\hline & $G$ & 8.3 & 12.2 & 12.6 & 16.4 \\
\hline
\end{tabular}

Palaeotemperatures calculated with the formula given by Epstein et al. (1953)

indicated by relict water occurring in strata below the Badenian evaporites - see discussion in Bukowski, 2011). Figures 14 and 15 show the interpreted palaeotemperature in three sections studied, assuming $\delta^{18} \mathrm{O}_{\text {water }}=0.1 \% \mathrm{SMOW}$, and Table 2 shows the ranges of palaeotemperatures for two taxa assuming various $\delta^{18} \mathrm{O}_{\text {water }}$ values: $-1,0,0.1$ and $1 \%$. For the palaeotemperature calculation of the total set of samples, the range of maximum and minimum values was established taking into account main values and the standard deviation (plus or minus).

In their study of Badenian foraminifera from the Vienna Basin Kováčová et al. (2009) assumed a $\delta^{18} \mathrm{O}_{\text {water }}$ of $0 \%$, and calculated palaeowater temperatures, if the equation of Epstein et al. (1953) is applied, would be $6.3-8.5^{\circ} \mathrm{C}$ for benthic foraminifers (mostly Uvigerina) and 9.7 to $17.7^{\circ} \mathrm{C}$ for Globigerina. Those values are similar to the results from this study. When $\delta^{18} \mathrm{O}_{\text {water }}$ of $0 \%$ is used for the calculation of palaeowater temperature, the ranges of mean values would be $6.3-7.8^{\circ} \mathrm{C}$ for Uvigerina and $10.1-13.8^{\circ} \mathrm{C}$ for Globigerina, and they increase to $11-11.7^{\circ} \mathrm{C}$ for Uvigerina and $10-18^{\circ} \mathrm{C}$ for Globigerina when a $\delta^{18} \mathrm{O}_{\text {water }}$ of $1 \%$ is used in calculations. In the modern Mediterranean $\delta^{18} \mathrm{O}_{\text {water }}=1 \%$ was recorded (Pierre, 1999), and in the Red Sea it is still higher $(2 \%$; Craig, 1966) while the Black Sea has a value of $-3 \%$ (Latal et al., 2006). Taking into account the geological context the existence of local variations of the $\delta^{18} \mathrm{O}_{\text {water }}$ in the Central Paratethys both in time and space casts no doubt.

However, there is a clear temporal change as far as the palaeotemperature of water in which foraminifers lived is concerned, at the boundary between the Orbulina suturalis and Uvigerina costai zones (Fig. 14; cf. Table 1). The average palaeotemperature of water based on the $\delta^{18} \mathrm{O}$ of Uvigerina decreased by ca. $2^{\circ} \mathrm{C}$ (from $9.9^{\circ} \mathrm{C}$ in the Orbulina suturalis Zone to $7.9^{\circ} \mathrm{C}$ in the Uvigerina costai Zone when $\delta^{18} \mathrm{O}_{\text {water }}=0.1 \%$
SMOW, and from 13.5 to $11.4^{\circ} \mathrm{C}$ when $\delta^{18} \mathrm{O}_{\text {water }}=1 \%$ SMOW). An even greater decrease (ca. $6^{\circ} \mathrm{C}$ ) is characteristic for Globigerina (from 17.4 in the Orbulina suturalis Zone to $11.5^{\circ} \mathrm{C}$ in the Uvigerina costai Zone when $\delta^{18} \mathrm{O}_{\text {water }}=0.1 \%$ SMOW, and from 21.5 to $15.2^{\circ} \mathrm{C}$ when $\delta^{18} \mathrm{O}_{\text {water }}=1 \%$ sMOW). In the Młyny (Busko) PIG 1 section only the uppermost part of the Orbulina suturalis Zone was available to study, so the earlier benthic oxygen isotope record remains enigmatic. In the Mediterranean Sea, this record shows a gradual trend toward heavier values between 14.95 and 13.95 Ma (Mourik et al., 2011; cf. Miller et al., 1991). As indicated by Mourik et al. (2011), between 14.0 and 13.9 Ma, open ocean records show a short interval characterized by relatively light benthic $\delta^{18} \mathrm{O}$ values associated with a warm phase, although this signal seems to be absent in the Mediterranean. In turn, no similar trend is observed in the planktonic $\delta^{18} \mathrm{O}$ record (Mourik et al., 2011). The global Middle Miocene cooling is reflected in the benthic oxygen isotope record, showing a $\sim 0.6 \%$ increase between $\sim 13.95$ and $13.76 \mathrm{Ma}$. Mourik et al. (2011) concluded that bottom water temperature in the Mediterranean did not change significantly at that time. Much stronger changes in the water palaeotemperature as indicated by both the benthic and planktonic $\delta^{18} \mathrm{O}$ records in the Młyny (Busko) PIG 1 section (Fig. 14) are in concert with the stronger signal of the Badenian cooling trend in the Carpathian Foredeep assumed by Bicchi et al. (2003) and Báldi (2006).

Below the gypsum, the $\delta^{18} \mathrm{O}$ values of both benthic and planktonic foraminifers show quite large variations (Figs. 14 and 15 ), which is possibly due to the salinity increase (see Peryt and Gedl, 2010, for discussion).

On the basis of sedimentological analyses, coastal upwelling has been repeatedly suggested for Central Paratethys during the Early Miocene (Grunert et al., 2010, with references therein) and the Middle Miocene (e.g., Gonera, 2001; Key et al., 2013). 
Foraminifers that calcify in an upwelling environment yield higher $\delta^{18} \mathrm{O}$ values and lower $\delta^{13} \mathrm{C}$ values (e.g., Faul et al., 2000; Peeters et al., 2002). Upwelling causes higher $\delta^{18} \mathrm{O}$ values in response to mixing with upwelled deeper, colder waters, and lower $\delta^{13} \mathrm{C}$ values result from mixing with upwelled deeper, more nutrient-rich waters containing older dissolved inorganic carbon with low $\delta^{13} \mathrm{C}$ values (Key et al., 2013, with references therein). Foraminiferal samples reported in this paper had a mean $\delta^{13} \mathrm{C}$ value of $-0.31 \%$ (Uvigerina) and $0.15 \%$ (Globigerina) and a mean $\delta^{18} \mathrm{O}$ value of $1.99 \%$ (Uvigerina) and $0.77 \%$ (Globigerina), and thus $\delta^{13} \mathrm{C}$ values are clearly lower than the range in mean global values (ca. $1.6 \%$ about 14 to $13.8 \mathrm{Ma}$; Zachos et al., 2001). The $\delta^{13} \mathrm{C}$ results can be interpreted as support for upwelling, and Key et al. (2013) suggested that there could have been upwelling along the northern margin of Carpathian Foredeep if the dominant winds were out of the west, as they could have caused upwelling due to the Coriolis effect (cf. Grunert et al., 2010). Contrary to expectations, the $\delta^{18} \mathrm{O}$ values of foraminifers determined in this study do not show the predicted higher values: the mean $\delta^{18} \mathrm{O}$ value for Uvigerina is around the mean global value (ca. 1.6 to $2.0 \%$ from 14 to $13.8 \mathrm{Ma}$; Zachos et al., 2001), and accordingly, I do not use isotope data from foraminifera to argue for upwelling in the studied part of Central Paratethys during the Middle Miocene.

\section{CONCLUSIONS}

1. Seventy-four samples of marls occurring below the midBadenian gypsum in three sections from the northern part of the Połaniec Trough, northern Polish Carpathian Foredeep Basin: Młyny (Busko) PIG 1 borehole section and Leszcze and Borków quarries, yielded rich foraminiferal assemblages. In the Młyny (Busko) PIG 1 borehole, sixty-seven benthic and twentyone planktonic taxa were found.

2. Benthic foraminiferal assemblages (mostly calcareous forms; agglutinated foraminifera are represented only by four species) of the studied interval (12 $\mathrm{m}$ thick) in the Młyny borehole are characterized by the dominance of Bulimina and Uvigerina. Planktonic foraminifers are composed mainly of warm-water orbulinids (Orbulina suturalis and O. bilobata) and Globigerinoides spp. in the lower part of the section and by cool-water Globigerina spp. in the upper part.

3. Taxonomic composition of foraminiferal assemblages makes it possible to distinguish two foraminiferal zones in the Młyny borehole: Orbulina suturalis and Uvigerina costai. The boundary between the two zones is located at a depth of
196.3 m. In the Leszcze and Borków quarries only the Uvigerina costai Zone is accessible.

4. The foraminiferal record from the Uvigerina costai Zone of the Młyny section indicates a longer period of high primary productivity and eutrophication of surface waters interrupted by a few short lasting periods with a return to mesotrophic or nearly oligotrophic conditions.

5. The benthic foraminiferal successions in the studied interval suggest oxygenation and productivity changes in the Carpathian Foredeep Basin prior to the Badenian salinity crisis. Four intervals of dysoxic conditions alternated with intervals with good oxygenation at the sea-floor, and eight assemblages have been distinguished in the Młyny section.

6 . The upsection decrease in the proportion of planktonic foraminifers reflects the shallowing of the basin accompanied by a decrease in the temperature gradient between the upper (warmer) and deeper (colder) waters. The replacement of intermediate warm-water planktonic foraminiferal assemblages by Globigerina-dominated assemblages (mainly G. bulloides) is related to the Middle Miocene climate transition widely recorded in the middle Badenian of the Paratethys area.

7. The $\delta^{18} \mathrm{O}$ and $\delta^{13} \mathrm{C}$ ratios of two foraminiferal taxa: Globigerina (in most cases, G. bulloides) and Uvigerina (mostly U. ex gr. peregrina), were studied in 52 samples. Total foraminiferal samples reported in this paper had a mean $\delta^{13} \mathrm{C}$ value of -0.31 \pm 0.43 for Uvigerina and $0.15 \pm 0.49 \%$ for Globigerina, and a mean $\delta^{18} \mathrm{O}$ value of $1.99 \pm 0.64 \%$ for Uvigerina and $0.77 \pm$ $0.95 \%$ for Globigerina. There is a clear change in the palaeotemperature of water in which foraminifers lived at the boundary between the Orbulina suturalis and Uvigerina costai zones. The average palaeotemperature of water based on the $\delta^{18} \mathrm{O}$ of Uvigerina decreased by ca. $2^{\circ} \mathrm{C}$ and based on the $\delta^{18} \mathrm{O}$ of Globigerina by ca. $6^{\circ} \mathrm{C}$. The observed changes in the water palaeotemperature are in concert with the stronger signal of the Badenian cooling trend in the Carpathian Foredeep assumed previously by Bicchi et al. (2003) and Báldi (2006).

8. Below the gypsum, the $\delta^{18} \mathrm{O}$ values of both benthic and planktonic foraminifers show quite large variations that are possibly due to the salinity increase.

Acknowledgements. This is contribution to the project on the Młyny (Busko) PIG 1 borehole initiated by A. Gasiewicz and G. Czapowski. I thank T. Lisek (ZG Kopalnia Gipsu "Leszcze" S.A.) and S. Gębka (Saint-Gobain Construction Products Polska) for permission to collect the samples and the journal reviewers (S. Filipescu, K. Holcová, N. Hudačková and M. Kaminski) for their comments.

\section{REFERENCES}

Abels H.A., Hilgen F.J., Krijgsman W., Kruk R.W., Raffi I., Turco E., Zachariasse W.J. (2005) Long-period orbital control on middle Miocene global cooling: Integrated stratigraphy and astronomical tuning of the Blue Clay Formation on Malta. Paleoceanography, 20: 1-17.

Alexandrowicz S.W. (1963) Stratigraphy of the Miocene deposits in the Upper Silesian basin (in Polish with English summary). Prace Instytutu Geologicznego, 39.

Alexandrowicz S.W., Parachoniak W. (1956) Miocene tuffites in the vicinity of Pińczów on the Nida river (in Polish with English summary). Acta Geologica Polonica, 6: 301-325.
Altenbach A.V., Pflaumann U., Schiebel R., Thies A., Timm S., Trauth M. (1999) Scaling percentages and distributional patterns of benthic foraminifera with flux rates or organic carbon. Journal of Foraminiferal Research, 29: 173-85.

Armstrong H., Brasier M. (2005) Microfossils. Blackwell Publishing.

Bąbel M. (1987) Giant gypsum intergrowths from the Middle Miocene evaporites of southern Poland. Acta Geologica Polonica, 37: 1-20.

Babel M. (1991) Dissolution of halite within the Middle Miocene (Badenian) laminated gypsum in southern Poland. Acta Geologica Polonica, 41: 163-182. 
Bąbel M., Olszewska-Nejbert D., Nejbert K. (2010) The largest giant gypsum intergrowths from the Badenian (Middle Miocene) evaporites of the Carpathian Foredeep. Geological Quarterly, 54 (4): 477-486.

Báldi K. (2006) Paleoceanography and climate of the Badenian (Middle Miocene, 16.4-13.0 Ma) in the Central Paratethys based on foraminifera and stable isotope $\left(\delta^{18} \mathrm{O}\right.$ and $\left.\delta^{13} \mathrm{C}\right)$ evidence. International Journal of Earth Sciences, 95: 119-142.

Báldi K., Hohenegger J. (2008) Paleoecology of benthic foraminifera of the Baden-Sooss section (Badenian, Middle Miocene, Vienna Basin, Austria). Geologica Carpathica, 59: 411-424.

Beldean C., Filipescu S., Bălc R. (2010) An Early Miocene biserial foraminiferal event in the Transylvanian Basin (Romania). Geologica Carpathica, 61: 227-234.

Bernhard J.M. (1986) Characteristic assemblages and morphologies of benthic foraminifera from anoxic organic-rich deposits: Jurassic through Holocene. Journal of Foraminiferal Research, 16: 207-215.

Bernhard J.M., Sen Gupta B. (1999) Foraminifera of oxygen-depleted environments. In: Modern Foraminifera (ed. B. Sen Gupta): 200-216. Kluwer Academic Publishers, Dordrecht.

Bicchi E., Ferrero E., Gonera M. (2003) Palaeoclimatic interpretation based on Middle Miocene planktonic foraminifera. The Silesia Basin (Paratethys) and Monferrato (Tethys) records. Palaeogeography, Palaeoclimatology, Palaeoecology, 196: 265-303.

Böhme M. (2003) The Miocene climatic optimum: evidence from ectothermic vertebrates of central Europe. Palaeogeography, Palaeoclimatology, Palaeoecology, 195: 389-401.

Broecker W.S., Peng T.-H. (1982) Tracers in the sea. Eldigio Press, Palisades, NY.

Bukowski K. (2011) Badenian saline sedimentation between Rybnik and Debica based on geochemical, isotopic and radiometric research (in Polish with English summary). Dissertations Monographs, 236.

Bukowski K., de Leeuw A., Gonera M., Kuiper K.F., Krzywiec P., Peryt D. (2010) Badenian tuffite levels within the Carpathian orogenic front (Gdów-Bochnia area, Southern Poland): radioisotopic dating and stratigraphic position. Geological Quarterly, 54 (4): 449-464.

Buzas H.A., Gibson T.G. (1969) Species diversity: benthonic foraminifera in Western North Atlantic. Science, 163 (3862): 72-75.

Cicha I., Rögl F., Rupp C., Čtyroká J. (1998) Oligocene - Miocene foraminifera of the Central Paratethys. Kramer, Frankfurt am Main.

Corliss B.H., Chen C. (1988) Morphotype patterns of Norwegian Sea deep-sea benthic foraminifera and ecological implications. Geology, 16: 716-719.

Craig H. (1966) Isotopic composition and origin of the Red Sea and Salton Sea geothermal brines. Science, 154: 1544-1548.

Culver S. (1988) New foraminiferal depth zonation of the northwestern Gulf of Mexico. Palaios, 3: 69-85.

Czapowski G. (2004) Otoczenie Gór Świętokrzyskich. In: Budowa geologiczna Polski (eds. T.M. Peryt and M. Piwocki), Tom I. Stratygrafia, Część 3a: 239-245. Państwowy Instytut Geologiczny, Warszawa.

De Leeuw A., Bukowski K., Krijgsman W., Kuiper K.F. (2010) The age of the Badenian Salinity Crisis; impact of Miocene climate variability on the Circum-Mediterranean region. Geology, 38: 715-718.

Di Stefano A., Verducci M., Lirer F., Ferraro L., laccarino S.M., Hüsing S.K., Hilgen F.J. (2010) Paleoenvironmental conditions preceding the Messinian Salinity Crisis in the Central Mediterranean: integrated data from the Upper Miocene Trave section (Italy). Palaeogeography, Palaeoclimatology, Palaeoecology, 297 (1): 37-53.

Drinia H., Antonarakou A., Tsaparas N., Kontakiotis G. (2007) Palaeoenvironmental conditions preceding the Messinian Salinity Crisis: a case study from Gavdos Island. Geobios, 40: 251-265.
Dudek K., Bukowski K. (2004) Badenian pyroclastic level from Gacki in Nida Valley, Carpathian Foredeep, Poland. Mineralogical Society of Poland - Special Papers, 24: 141-144.

Dudziak J., Łuczkowska E. (1991) Biostratigraphic correlation of foraminiferal and calcareous nannoplankton zones, Early-Middle Badenian (Miocene), Southern Poland. Bulletin of the Polish Academy of Sciences, Earth Sciences, 39: 199-214.

Durakiewicz T., Gonera M., Peryt T.M. (1997) Oxygen and carbon isotopic changes in the Middle Miocene (Badenian) foraminifera of the Gliwice area (SW Poland). Bulletin of the Polish Academy of Sciences, Earth Sciences, 45: 145-156.

Epstein S., Buchsbaum R., Lowenstam H.A., Urey H.C. (1953) Revised carbonate - water temperature scale. GSA Bulletin, 64: $1315-1326$

Erez J., Luz B. (1983) Experimental paleotemperature equation for planktonic foraminifera. Geochimica et Cosmochimica Acta, 47: 1025-1031.

Faul K.L., Ravelo A.C., Delaney M.L. (2000) Reconstructions of upwelling, productivity, and photic zone depth in the eastern equatorial Pacific Ocean using planktonic foraminiferal stable isotopes and abundances. Journal of Foraminiferal Research, 30: $110-125$.

Filipescu S., Silye L. (2008) New Paratethyan biozones of planktonic foraminifera described from the Middle Miocene of the Transylvanian Basin. Geologica Carpathica, 59: 537-544.

Gonera M. (2001) Foraminiferida and paleoenvironment of the Badenian formations (Middle Miocene) in the Upper Silesia (Poland) (in Polish with English summary). Studia Naturae, 48: $1-211$.

Gonera M., Bukowski K. (2012) Isotopic events in the Early/Middle Badenian (Miocene) of the Upper Silesia Basin (Central Paratethys). Geological Quarterly, 56 (3): 561-568.

Gonera M., Peryt T.M., Durakiewicz T. (2000) Biostratigraphical and palaeoenvironmental implications of isotopic studies $\left({ }^{18} \mathrm{O}\right.$, ${ }^{13} \mathrm{C}$ ) of middle Miocene (Badenian) foraminifers in the Central Paratethys. Terra Nova, 12: 231-238.

Gonera M., Bukowski K., d'Obyrn K., Wiewiórka J. (2012) Foraminifera in slump deposits of the Badenian (Middle Miocene) Green Stratified Salt in Wieliczka, Poland. Geological Quarterly, 56 (4): 869-880.

Gooday A.J., Hughes J.A., Levin L.A. (2001) The foraminiferan macrofauna from three North Carolina (USA) slope sites with contrasting carbon flux: a comparison with the metazoan macrofauna. Deep-Sea Research I, 48: 1709-1739.

Grunert P., Soliman A., Harzhauser M., Müllegger S., Piller W.E., Roetzel R., Rögl F. (2010) Upwelling conditions in the Early Miocene Central Paratethys Sea. Geologica Carpathica, 61: 129-145.

Harzhauser M., Piller W.E. (2007) Benchmark data of a changing sea - palaeogeography, palaeobiogeography and events in the Central Paratethys during the Miocene. Palaeogeography, Palaeoclimatology, Palaeoecology, 253: 8-31.

Hemleben C., Spindler M., Anderson O.R. (1989) Modern planktonic foraminifera. Springer Verlag, New York.

Hilgen F.J., Abels H.A., laccarino S., Krijgsman W., Raffi I., Sprovieri R., Turco E., Zachariasse W.J. (2009) The global stratotype section and point (GSSP) of the Serravallian Stage (Middle Miocene). Episodes, 32: 152-166.

Hohenegger J. (2005) Estimation of environmental paleogradient values based on presence/absence data: a case study using benthic foraminifera for paleodepth estimation. Palaeogeography, Palaeoclimatology, Palaeoecology, 217: 115-130.

Holcová K., Demény A. (2012) The oxygen and carbon isotopic composition of Langhian foraminiferal tests as a palaeoecological proxy in a marginal part of the Carpathian Foredeep (Czech Republic). Geologica Carpathica, 63 (2): 121-137.

Hudáčková N., Spezzaferri S. (2002) Statistical approach to reconstruct palaeoenvironments: an example from the Miocene of Devínska Nová Ves (Central Paratethys, Vienna Basin, Slovak part). EMMM'2002, Abstract Book Vienna: 99-101. 
Jasionowski M. (1997) Lithostratigraphy of the Miocene deposits in the eastern part of the Carpathian Foredeep (in Polish with English summary). Biuletyn Państwowego Instytutu Geologicznego, 375: 43-60.

Jiménez-Moreno G., Rodríguez-Tovar F.J., Pardo-Igúzquiza E., Fauquette S., Suc J.-P., Müller P. (2005) High-resolution palynological analysis in late early-middle Miocene core from the Pannonian Basin, Hungary: climatic changes, astronomical forcing and eustatic fluctuations in the Central Paratethys. Palaeogeography, Palaeoclimatology, Palaeoecology, 216: 73-97.

Jorissen F.J., Barmavidjaja D.M., Puskaric S., van der Zwaan G.J. (1992) Vertical distribution of benthic foraminifera in the northern Adriatic Sea: the relation with the organic flux. Marine Micropaleontology, 19: 131-146.

Jorissen F.J., de Stigter H.C., Widmark J.G.V. (1992) A conceptual model explaining benthic foraminiferal microhabitats. Marine Micropaleontology, 26: 3-15.

Kaiho K. (1994) Benthic foraminiferal dissolved-oxygen index and dissolved oxygen levels in the modern ocean. Geology, 22 719-722.

Kaminski M.A. (2012) Calibration of the Benthic Foraminiferal Oxygen Index in the Marmara Sea. Geological Quarterly, 56 (4): 757-764.

Kasprzyk A. (1991) Lithofacies analysis of the Badenian sulfate deposits south of the Holy Cross Mts. (in Polish with English summary). Przegląd Geologiczny, 39: 213-223.

Kasprzyk A. (1993) Lithofacies and sedimentation of the Badenian (Middle Miocene) gypsum in the northern part of the Carpathian Foredeep, southern Poland. Annales Societatis Geologorum Poloniae, 63: 33-84.

Key M.M. Jr., Zágoršek K., Patterson W.P. (2013) Paleoenvironmental reconstruction of the Early to Middle Miocene Central Paratethys using stable isotopes from bryozoan skeletons. International Journal of Earth Sciences, 102: 305-318.

Kouwenhoven T.J., van der Zwaan G.J. (2006) A reconstruction of late Miocene Mediterranean circulation patterns using benthic foraminifera. Palaeogeography, Palaeoclimatology, Palaeoecology, 238: 373-385.

Kováčová P., Hudáčková N. (2009) Late Badenian foraminifers from the Vienna Basin (Central Paratethys): stable isotope study and paleoecological implications. Geologica Carpathica, 60: 59-70.

Kováčová P., Emmanuel L., Hudáčková N., Renard M. (2009) Central Paratethys paleoenvironment during the Badenian (Middle Miocene): evidence from foraminifera and stable isotope $\left(\delta^{13} \mathrm{C}\right.$ and $\left.\delta^{18} \mathrm{O}\right)$ study in the Vienna Basin (Slovakia). International Journal of Earth Sciences, 98: 1109-1127.

Kwiatkowski S. (1974) Miocene gypsum deposits in southern Poland (in Polish with English summary). Biuletyn Instytutu Geologicznego, 280: 299-344.

Latal C., Piller W.E., Harzhauser M. (2006) Shifts in oxygen and carbon isotope signals in marine molluscs from the Central Paratethys (Europe) around the Lower/Middle Miocene transition. Palaeogeography, Palaeoclimatology, Palaeoecology, 231: 347-360.

Loeblich A.R. Jr., Tappan H. (1987) Foraminiferal Genera and their Classification. Van Nostrand Reinhold, New York.

Loubère P. (1996) The surface ocean productivity and bottomwater oxygen signals in deep water benthic foraminiferal assemblages. Marine Micropaleontology, 28: 247-261.

Loubère P. (1997) Benthic foraminiferal assemblage formation, organic carbon flux and oxygen concentrations on the outer continental shelf and slope. Journal of Foraminiferal Research, 27 (2): 93-100

Lozar F., Violanti D., Dela Pierre F., Bernardi E., Cavagna S., Clari P., Irace A., Martinetto E., Trenkwalder S. (2010) Calcareous nannofossils and foraminifers herald the Messinian Salinity Crisis: the Pollenzo section (Alba, Cuneo; NW Italy). Geobios, 43: 21-31.
Lutze G.F., Coulbourn W.T. (1984) Recent benthic foraminifera from the continental margin of northwest Africa: community structure and distribution. Marine Micropaleontology, 8: 361-401.

Lutze G.F., Thiel H. (1989) Epibenthic foraminifera from elevated microhabitats; Cibicidoides wuellerstorfi and Planulina ariminensis. Journal of Foraminiferal Research, 19 (2): 153-158.

Łuczkowska E. (1964) The micropaleontological stratigraphy of the Miocene in the region Tarnobrzeg-Chmielnik (in Polish with English summary). Prace Geologiczne, 20: 7-72.

Majewski W. (2003) Water-depth distribution of Miocene planktonic foraminifera from ODP Site 744, Southern Indian Ocean. Journal of Foraminiferal Research, 33: 144-154.

Majewski W., Bohaty S.M. (2010) Surface-water cooling and salinity decrese during the Middle Miocene climate transition at Southern Ocean ODP Site 747 (Kerguelen Plateau). Marine Micropaleontology, 74: 1-14.

Mandic O., Harzhauser M., Spezzaferri S., Zuschin M. (2002) The paleoenvironment of an early Middle Miocene Paratethys sequence in NE Austria with special emphasis on paleoecology of mollusks and foraminifera. Geobios, 35 (M.S. 24): 193-206.

McCorkle D.C., Keigwin L.D., Corliss B.H., Emerson S.R. (1990) The influence of microhabitats on the carbon isotopic composition of deep-sea benthic foraminifera. Paleoceanography, 5: 161-185.

Miller K.G., Wright J.D., Fairbanks R.G. (1991) Unlocking the ice house: Oligocene-Miocene oxygen isotopes, eustasy, and margin erosion. Journal of Geophysical Research, 96: 6829-6848.

Mourik A.A., Abels H.A., Hilgen F.J., Di Stefano A., Zachariasse W.J. (2011) Improved astronomical age constraints for the middle Miocene climate transition based on high-resolution stable isotope records from the central Mediterranean Maltese Islands. Paleoceanography, 26, PA1210, doi: 10.1029/2010PA001981

Murray J.W. (1991) Ecology and palaeoecology of benthic foraminifera. Longman, Avon.

Murray J.W. (2006) Ecology and applications of benthic foraminifera. Cambridge University Press, Cambridge.

Odrzywolska-Bieńkowa E., Olszewska B. (1996) Rząd Foraminiferida Eichwald. In: Budowa geologiczna Polski (eds. L. Malinowska and M. Piwocki): 530-614. Atlas skamieniałości przewodnich i charakterystycznych, część 3a. Państwowy Instytut Geologiczny, Warszawa.

Oszczypko N., Krzywiec P., Popadyuk I., Peryt T. (2006) Carpathian Foredeep Basin (Poland and Ukraine): its sedimentary, structural, and geodynamic evolution. AAPG Memoir, 84: 293-350.

Oszczypko-Clowes M., Lelek D., Oszczypko N. (2012) Sarmatian paleoecological environment of the Machów Formation based on the quantitative nannofossil analysis - a case study from the Sokołów area (Polish Carpathian Foredeep). Geologica Carpathica, 63 (4): 267-294.

Peeters F.J.C., Brummer G.-J.A., Ganssen G. (2002) The effect of upwelling on the distribution and stable isotope composition of Globigerina bulloides and Globigerina ruber (planktic foraminifers) in modern surface waters of the NW Arabian Sea. Global and Planetary Change, 34: 269-291.

Perez-Cruz L.L., Machain-Castillo M.L. (1990) Benthic foraminifera of the oxygen minimum zone, continental shelf of the Gulf of Tehuantepec, Mexico. Journal of Foraminiferal Research, 20: 312-325.

Peryt D. (1997) Calcareous nannoplankton stratigraphy of the Middle Miocene in the Gliwice area (Upper Silesia, Poland). Bulletin of the Polish Academy of Sciences, Earth Sciences, 45: 119-131.

Peryt D. (2013) Foraminiferal record of marine transgression during deposition of the Middle Miocene Badenian evaporites in Central Paratethys (Borków section, Polish Carpathian Foredeep). Terra Nova, doi: 10.1111/ter.12036

Peryt D., Gedl P. (2010) Palaeoenvironmental changes preceding the Middle Miocene Badenian salinity crisis in the northern Polish Carpathian Foredeep Basin (Borków Quarry) inferred from 
foraminifers and dinoflagellate cysts. Geological Quarterly, $\mathbf{5 4}$ (4): 487-508.

Peryt D., Alegret L., Molina E. (2002) The Cretaceous/Paleogene (K/P) boundary at Ain Settara (Tunisia): restructuring of benthic foraminiferal assemblages. Terra Nova, 14: 101-107.

Pierre C. (1999) The oxygen and carbon isotope distribution in the Mediterranean water masses. Marine Geology, 153: 41-55.

Popov S.V., Rögl F., Rozanov A.Y., Steininger F.F., Shcherba I.G., Kováč M., eds. (2004) Lithological-paleogeographic maps of Paratethys. Courier Forschungsinstitut Senckenberg, 250: 1-46.

Pujol C., Vergnaud-Grazzini C. (1995) Distribution patterns of live planktic foraminifers as related to regional hydrography and productive systems of the Mediterranean Sea. Marine Micropaleontology, 25: 187-217.

Radwański A. (1969) Lower Tortonian transgression onto the southern slopes of the Holy Cross Mts. (in Polish with English summary). Acta Geologica Polonica, 19: 1-164.

Rögl F. (1998) Palaeogeographic considerations for Mediterranean and Paratethys seaways (Oligocene to Miocene). Annalen des Naturhistorischen Museums in Wien, 99: 279-310.

Shackleton N.J. (1974) Attainment of isotopic equilibrium between ocean water and benthonic foraminifera genus Uvigerina: isotopic changes in the ocean during the last glacial. Colloques Internationals C.N.R.S., 219: 203-209.

Sjoerdsma P.G., van der Zwaan G.J. (1992) Simulating the effect of changing oceanic flux and oxygen content on the distribution of benthic foraminifers. Marine Micropaleontology, 19: 163-180.

Spezzaferri S., Ćorić S., Hohenegger J., Rögl F. (2002) Basin-scale paleobiogeography and paleoecology: an example from Karpatian (Latest Burdigalian) benthic and planktonic foraminifera and calcareous nannofossils from the Central Paratethys. Geobios, Mémoire special, 24: 241-256.

Szczechura J. (1982) Middle Miocene foraminiferal biochronology and ecology of SE Poland. Acta Palaeontologica Polonica, 27: $3-44$.

Szczechura J. (1984) Morphologic variability in the Globigerinoides-Orbulina group from the Middle Miocene of the Central Paratethys. Acta Palaeontologica Polonica, 29: 3-27.
Szczechura J. (2000) Age and evolution of depositional environments of the supra-evaporitic deposits in the northern, marginal part of the Carpathian Foredeep: micropalaeontological evidence. Geological Quarterly, 44 (1): 81-100.

Thomas E. (1980) Details of Uvigerina development in the Cretan Mio-Pliocene. Utrecht Micropaleontological Bulletins, 23: 1-167.

Thomas E. (1990) Late Cretaceous through Neogene deep-sea benthic foraminifers (Maud Rise, Weddell Sea, Antarctica). Proceedings ODP, Scientific Results, 113B: 571-594.

Van der Zwaan G.J. (1982) Paleoecology of late Miocene Mediterranean Foraminifera. Utrecht Micropaleontological Bullettins, 25: 202.

Van der Zwaan G.J. (1983) Quantitative analysis and the reconstruction of benthic foraminiferal communities. Reconstruction of marine paleoenvironments. Utrecht Micropaleontological Bulletins, 30: 49-69.

Van der Zwaan G.J., Duijnstee I.A.P., den Dulk M., Ernst S.R., Jannink N.T., Kouwenhoven T.J. (1999) Benthic foraminifers: proxies or problems? A review of paleocological concepts. Earth-Science Reviews, 46: 213-236.

Van Hinsbergen D.J.J., Kouwenhoven T.J., van der Zwaan G.J. (2005) Paleobathymetry in the backstripping procedure: correction for oxygenation effects on depth estimates. Palaeogeography, Palaeoclimatology, Palaeoecology, 221: 245-265.

Verhallen P. (1991) Late Pliocene to early Pleistocene Mediterranean mud-dwelling foraminifera; influence of a changing environment on community structure and evolution. Utrecht Micropaleontological Bulletins, 40: 1-219.

Wilczyński M. (1984) Tektonika obszaru między Chmielnikiem, Szydłowem i Wiślica w świetle danych geologicznych w tym zdjęć radarowych i satelitarnych. Ph.D. thesis. Central Geological Archive, Warszawa.

Zachos J., Pagani M., Sloan L., Thomas E., Billups K. (2001) Trends, rhythms, and aberrations in global climate $65 \mathrm{Ma}$ to present. Science, 292 (5517): 686-693. 